\title{
Avian mercury exposure and toxicological risk across western North America: A synthesis
}

Joshua T. Ackerman, ${ }^{\mathrm{a}, *}$ Collin A. Eagles-Smith, ${ }^{\mathrm{b}}$ Mark P. Herzog, ${ }^{\mathrm{a}}$ C. Alex Hartman, ${ }^{\mathrm{a}}$ Sarah H. Peterson, ${ }^{\mathrm{a}}$ David C. Evers, ${ }^{\mathrm{c}}$ Allyson K. Jackson, ${ }^{\mathrm{d}}$ John E. Elliott, ${ }^{\mathrm{e}}$ Stacy S. Vander Pol, ${ }^{\mathrm{f}}$ and Colleen E. Bryan ${ }^{\mathrm{f}}$

${ }^{a}$ U.S. Geological Survey, Western Ecological Research Center, Dixon Field Station, 800 Business Park Drive, Suite D, Dixon, California 95620, United States

${ }^{\mathrm{b}}$ U.S. Geological Survey, Forest and Rangeland Ecosystem Science Center, 3200 SW Jefferson Way, Corvallis, Oregon, 97331, United States

${ }^{\mathrm{c}}$ Biodiversity Research Institute, 276 Canco Road, Portland, Maine, 04103, United States

${ }^{\mathrm{d}}$ Oregon State University, Department of Fisheries and Wildlife, 104 Nash Hall, Corvallis, Oregon, 97331, United States

${ }^{\mathrm{e}}$ Environment Canada, Science and Technology Branch, Pacific Wildlife Research Centre, Delta, British Columbia V4K 3N2, Canada

${ }^{\mathrm{f}}$ National Institute of Standards and Technology, Chemical Sciences Division, Hollings Marine Laboratory, 331 Fort Johnson Road, Charleston, South Carolina, 29412, United States

Word Count: 14,327; with 2 tables and 9 figures; and 73 pages of Supporting Material

*Corresponding Author

e-mail: jackerman@usgs.gov

March 10, 2016 


\begin{abstract}
Methylmercury contamination of the environment is an important issue globally, and birds are useful bioindicators for mercury monitoring programs. The available data on mercury contamination of birds in western North America were synthesized. Original data from multiple databases were obtained and a literature review was conducted to obtain additional mercury concentrations. In total, 29219 original bird mercury concentrations from 225 species were compiled, and an additional 1712 mean mercury concentrations, representing 19998 individuals and 176 species, from 200 publications were obtained. To make mercury data comparable across bird tissues, published equations of tissue mercury correlations were used to convert all mercury concentrations into blood-equivalent mercury concentrations. Blood-equivalent mercury concentrations differed among species, foraging guilds, habitat types, locations, and ecoregions. Piscivores and carnivores exhibited the greatest mercury concentrations, whereas herbivores and granivores exhibited the lowest mercury concentrations. Bird mercury concentrations were greatest in ocean and salt marsh habitats and lowest in terrestrial habitats. Bird mercury concentrations were above toxicity benchmarks in many areas throughout western North America, and multiple hotspots were identified. Additionally, published toxicity benchmarks established in multiple tissues were summarized and translated into a common blood-equivalent mercury concentration. Overall, $66 \%$ of birds sampled in western North American exceeded a blood-equivalent mercury concentration of $0.2 \mu \mathrm{g} / \mathrm{g}$ wet weight (ww; above background levels), which is the lowest-observed effect level, $28 \%$ exceeded $1.0 \mu \mathrm{g} / \mathrm{g}$ ww (moderate risk), $8 \%$ exceeded $3.0 \mu \mathrm{g} / \mathrm{g}$ ww (high risk), and $4 \%$ exceeded $4.0 \mu \mathrm{g} / \mathrm{g}$ ww (severe risk). Mercury monitoring programs should sample bird tissues, such as adult blood and eggs, that are mosteasily translated into tissues with well-developed toxicity benchmarks and that are directly relevant to bird reproduction. Results indicate that mercury contamination of birds is prevalent in many areas throughout western North America, and large-scale ecological attributes are important factors influencing bird mercury concentrations.
\end{abstract}

\title{
Key Words
}

Birds, blood equivalent, Eggs, Bioaccumulation, Toxicity Benchmarks

\section{Introduction}

Methylmercury contamination of the environment is an important issue globally because of continued anthropogenic emissions of mercury over time (Driscoll et al., 2013; Eagles-Smith et al., submitted to this issue; Weiss-Penzias et al., submitted to this issue), its ability to biomagnify through (primarily) aquatic food chains (Wiener et al., 2003), and its documented negative effects on fish and wildlife (Scheuhammer et al., 2007; Wiener et al., 2003). Birds are ubiquitous, top predators in many aquatic and terrestrial habitats, and often are subjected to elevated methylmercury concentrations (Cristol et al., 2008; Eagles-Smith et al., 2009a). Bird reproduction is particularly sensitive to mercury toxicity, with numerous documented deleterious effects to bird health, condition, behavior, and productivity (Table 1; Scheuhammer et al., 2007; Wiener et al., 2003). Together, these characteristics make birds useful bioindicators for local mercury contamination and regional monitoring programs (Day et al., 2012; Evers et al., 2011; Monteiro and Furness, 1995; Provencher et al., 2014; Weseloh et al., 2011).

Large-scale assessments of environmental pollution can be helpful for understanding the major drivers and distributions of contaminants in animals. A few studies have synthesized the 
available data on bird mercury contamination within the Great Lakes and northeastern regions of the United States and Canada (Evers et al., 2011; Jackson et al., 2015) and the Canadian Arctic (Mallory and Braune, 2012), but no such studies exist elsewhere in North America. Western North America is characterized by a diverse gradient of habitats, including both extremely dry and wet regions (National Assessment Synthesis Team, 2001). In particular, ephemeral wetland habitats are common across western North America (Tiner, 1984). The temporary wetting and drying of wetland habitats is often associated with biogeochemical conditions that tend to promote the methylation of inorganic mercury to its more toxic form, methylmercury (Ullrich et al., 2001). These ephemeral wetlands also tend to be highly productive and are greatly utilized by birds as foraging habitat (Murkin et al., 1997; Niemuth et al., 2006; Skagen et al., 2008). In addition to habitat-specific effects, mercury contamination in birds typically differs among foraging guilds, trophic levels, and species (Anderson et al., 2009; Blévin et al., 2013; EaglesSmith et al., 2009a). Examining these effects over a large geographic area may identify hotspots of methylmercury contamination within bird populations, aid in prioritizing contaminant monitoring programs (Mason et al., 2005), and focus policy-making decisions.

In this synthesis paper, the available data on mercury contamination of birds in western North America are summarized. To do so, original, raw data from multiple databases were obtained and the literature was reviewed (published articles and reports) to extract mean mercury concentrations in birds for each species and site that has been studied. In total, nearly 30000 original, individual bird mercury concentrations from 225 species were compiled, and an additional >1700 mean mercury concentrations, representing nearly 20000 individuals and 176 species, from 200 publications were obtained. The goals were to describe the distribution of bird mercury contamination in western North America, identify potential hotspots, and examine the major factors influencing bird mercury concentrations. Specifically, influence of species, foraging guild, habitat, ecoregion, and location on mercury contamination were examined for western North American birds. Additionally, the literature was reviewed, published toxicity benchmarks were summarized, and toxicity benchmarks established in multiple bird tissues were translated into a common blood-equivalent mercury concentration to integrate toxicity risk across avian life-stages and tissues. These toxicity benchmarks were then used to assess the toxicological risk of mercury exposure to birds in western North America.

\section{Material and methods}

\subsection{Data acquisition: original data}

Original data on mercury concentrations in individual birds from several sources were obtained. The U.S. Fish and Wildlife Service's Environmental Contaminants Data Management System (ECDMS) database (retrieved August 27, 2013), which contributed 25\% of the data points, is an online database that houses contaminant data collected by government agencies. Additional original data were obtained from the authors' unpublished datasets at the U.S. Geological Survey (61\% of the data); Biodiversity Research Institute (12\%); the multi-partner Seabird Tissue and Archival Monitoring Project (STAMP; 2\%); and Environment Canada $(<1 \%)$. The databases were then merged, data was reviewed for quality, and the following information was extracted: bird species, tissue type (egg, whole blood, muscle, liver, kidney, and feathers), location (latitude and longitude), year, total mercury or methylmercury concentration, and units of measurement (including if data were reported in wet weight or dry weight). When location data were not reported within the study, study site descriptions (e.g., county or lake 
names) were used to assign approximate latitudes and longitudes using Google Earth ${ }^{\mathrm{TM}}$. Any incomplete data, including studies whose locations could not be determined, were excluded.

\subsection{Data acquisition: literature review}

A thorough literature review of all peer-reviewed journal articles and published reports documenting mercury concentrations in birds in western North America was conducted. Literature searches were conducted in Web of Science ${ }^{\mathrm{TM}}$ and Google Scholar ${ }^{\mathrm{TM}}$. For each study, the following information was extracted: bird species, tissue type, location (latitude and longitude), year, mean mercury concentration, units of measurement (including if data were reported in wet weight or dry weight), and sample size. Sometimes, year was reported as a range and, in these cases, the midpoint was used. When year was not reported, the publication year minus one was applied. Similarly, when sample sizes were reported as ranges, the midpoint was used as the sample size. When composite samples were used in a study, the number of composite samples was multiplied by the number of individual samples within the composites to calculate the effective sample size that was used in the study to produce the grand mean. When mean mercury concentrations were obtainable only from figures, rather than as values in a table or the text, the mean mercury concentration was visually approximated within the figure. Within the same study, mean mercury concentrations were kept separate for each species and location when possible; this often resulted with a single publication contributing multiple mean mercury concentrations, one mean for each species and location within the study. When location data were not reported within the study, study site descriptions (e.g., county and lake names) were used to assign approximate latitudes and longitudes using Google Earth ${ }^{\mathrm{TM}}$.

\subsection{Assigning bird taxonomy, foraging guilds, and habitats}

For both the original and literature-review data, each species was assigned to a foraging guild and general habitat type. Taxonomy was based on the seventh edition of the American Ornithologists' Union's Checklist of North and Middle American Birds (retrieved August 13, 2013 from http://checklist.aou.org/). Bird species were assigned to foraging guilds following DeGraaf et al. (1985) with the following modifications: (1) when a bird species occurred in multiple foraging guilds, such as piscivore and crustaceovore for several coastal seabirds, the primary foraging guild was used, and (2) when foraging guild differed by season (breeding, nonbreeding, or year round), the foraging guild for the breeding season was used because most of the mercury data were from eggs or adults during the breeding season. Foraging guilds were categorized as piscivore, carnivore, insectivore, crustaceovore, molluscovore, vermivore, omnivore, granivore, or herbivore. Bird species were assigned to the following general habitats: ocean, coastal, salt marsh, both fresh and brackish water, freshwater, terrestrial-canopy, terrestrial-lower canopy, and terrestrial-ground. Habitats were assigned using DeGraaf et al.'s (1985) classifications as well as the Birds of North America series' (http://bna.birds.cornell.edu/bna/) habitat descriptions. All avian taxa (including order, family, and species), foraging guilds, and habitats are summarized in Table S1.

\subsection{GIS data layers}

Geographic Information Systems (GIS; ArcGIS 10.2, Environmental Research Systems Institute, Redlands, CA, USA) were used to attribute each sample location with landscape variables, including ecoregion and $100-\mathrm{km} \times 100-\mathrm{km}$ grid cell. The U.S. Environmental 
Protection Agency's ecoregion level one category (Commission for Environmental Cooperation, 1997), which separates North America into 15 distinct ecoregions, was used and two additional categories were added: one for samples collected in the Pacific and Arctic Oceans (including various small islands and atolls), and one for samples collected on the Hawaiian Islands, for a total of 17 possible ecoregions. The Create Fishnet geoprocessing tool (ArcGIS 10.2) was used to create a grid of cells, each measuring $100 \mathrm{~km} \times 100 \mathrm{~km}$, across the extent of the sample locations in western North America, and then the Spatial Join geoprocessing tool (ArcGIS 10.2) was used to attribute each data point with the ecoregion and grid cell it occupied. Distribution maps of mercury concentrations in birds throughout western North America were produced using ArcGIS 10.2, and overlaid on a physical base layer provided by the U.S. National Park Service.

\subsection{Data transformations and assumptions}

Numerous data assumptions and transformations were necessary to consolidate, organize, and convert various tissue types and concentration units into similar values. First, only the following tissues were included: whole blood, eggs, muscle, liver, kidney, and fully grown feathers. These tissues represented $>98 \%$ of the available data, and they are more readily comparable to one-another than the other available tissues, such as whole carcass. Second, data from any laboratory dosing or artificial studies that did not represent data from wild birds were excluded. Data from hazard assessments were included, because the impetus for a large number of studies was a known or suspected hazard (especially within the ECDMS dataset). Third, data were included only for eggs, adult tissues, or post-fledged juveniles. Samples collected from pre-fledged juveniles were excluded, because chicks undergo rapid changes in mercury concentrations in internal tissues as they grow and age (Ackerman et al., 2011) making any comparisons difficult. Fourth, data for both total mercury and methylmercury were included. All mercury in eggs (Ackerman et al., 2013), whole blood (Rimmer et al., 2005), muscle (Scheuhammer et al., 1998), and feathers (Thompson and Furness, 1989) was assumed to be in the methylmercury form, and, therefore, total mercury and methylmercury concentrations were used to represent methylmercury concentrations in birds. A significant proportion of the mercury in liver and kidney can be in the inorganic form (Eagles-Smith et al., 2009b; Scheuhammer et al., 1998; Thompson and Furness, 1989). Very few data (<1\%) were available for these tissues as methylmercury concentrations, but, for those limited data, methylmercury concentrations were transformed into equivalent total mercury $(\mathrm{THg})$ concentrations by using an adjustment of $88 \%$ of THg being in the methylmercury form in liver (Eagles-Smith et al., 2009b). This assumption was justified because most data occurred below the $8.5 \mu \mathrm{g} / \mathrm{g}$ dry weight (dw) liver threshold where demethylation begins, above which a smaller proportion of THg as methylmercury would be expected in the liver (Eagles-Smith et al., 2009b). No adjustments were necessary for methylmercury concentrations in kidney, because $\mathrm{THg}$ concentrations were always available when methylmercury concentrations in kidneys were reported. Fifth, to make the mercury data comparable across bird tissues, all tissue concentrations were converted into blood-equivalent $\mathrm{THg}$ concentrations $(\mu \mathrm{g} / \mathrm{g})$ in wet weight (ww) using multiple equations from Eagles-Smith et al. (2008) and Ackerman et al. (2016a) detailed below. Before using these equations, it was necessary to convert $\mathrm{THg}$ concentration data from each tissue compartment into the same units, and thus all muscle, liver, kidney, and feather data were converted into dry weight $\mathrm{THg}$ concentrations $(\mu \mathrm{g} / \mathrm{g} \mathrm{dw})$ using the reported percent moisture in the sample. Likewise, blood data were converted into wet weight $\mathrm{THg}$ 
concentrations $(\mu \mathrm{g} / \mathrm{g} \mathrm{ww})$ using the reported percent moisture in the sample in the few instances $(<1 \%)$ where blood was reported in dry weight. When moisture content was not reported, an average moisture content of $79 \%$ in blood, $67 \%$ in liver, $70 \%$ in muscle, and $74 \%$ in kidney was used (Eagles-Smith et al., 2008). For eggs, it is important to report mercury concentrations on a fresh wet weight (fww) basis (Ackerman et al., 2013; Stickel et al., 1973); however, the necessary egg morphometrics to make these adjustments were not available in many of the raw datasets and this made the conversion to fresh wet weight not possible. Therefore, when egg morphometric data were unavailable, egg THg concentrations $(\mu \mathrm{g} / \mathrm{g})$ were converted on a dry weight basis into a wet weight basis using the reported percent moisture in the individual egg or, when moisture content was not reported, an average egg moisture content of $75 \%$ was used (Ackerman et al., 2013). When egg morphometric data were available (i.e., authors' data), THg concentrations on a fresh wet weight basis $(\mu \mathrm{g} / \mathrm{g}$ fww) were used and calculated following Ackerman et al. (2013). In one instance, only albumen $\mathrm{THg}$ concentrations $(\mu \mathrm{g} / \mathrm{g} \mathrm{ww})$ were reported, and the albumen $\mathrm{THg}$ concentration was converted into a whole-egg $\mathrm{THg}$ concentration ( $\mu \mathrm{g} / \mathrm{g}$ fww) using the predictive equation in Stebbins et al. (2009), before conversion into a blood-equivalent $\mathrm{THg}$ concentration. Hereafter, all egg $\mathrm{THg}$ concentrations are reported as simply $\mu \mathrm{g} / \mathrm{g} w \mathrm{w}$. For most analyses, data points that were derived from the same bird, but in a different tissue, were excluded. Priority was given to tissues from the same bird in the following order: whole blood, eggs, muscle, liver, kidney, and fully grown feathers (see Table 2).

To convert THg concentrations in bird tissues into THg concentrations in blood, the following equations (eqs. 1-4) from Eagles-Smith et al. (2008), which were developed from >600 birds of 4 bird species with a broad range of tissue THg concentrations, were used. For the feather equation, the predictive equation for breast feathers, rather than head feathers, was used because most of the feathers sampled are typically body feathers and this differentiation among feather types was not usually reported.

$$
\begin{aligned}
& \left(\text { eq. } 1 ; R^{2}=0.90\right): \ln \left(\text { Blood THg } \frac{\mu g}{g} w w\right)=1.080 \times \ln \left(\text { Bird Muscle THg } \frac{\mu g}{g} d w\right)-1.024 \\
& \left(\text { eq. } 2 ; R^{2}=0.88\right): \ln \left(\text { Blood } T H g \frac{\mu g}{g} w w\right)=0.970 \times \ln \left(\text { Bird Liver THg } \frac{\mu g}{g} d w\right)-1.929 \\
& \left(\text { eq. } 3 ; R^{2}=0.87\right): \ln \left(\text { Blood THg } \frac{\mu g}{g} w w\right)=1.003 \times \ln \left(\text { Bird Kidney THg } \frac{\mu g}{g} d w\right)-2.008 \\
& \left(\text { eq. } 4 ; R^{2}=0.32\right): \ln \left(\text { Blood THg } \frac{\mu g}{g} w w\right)=0.673 \times \ln \left(\text { Bird Feather THg } \frac{\mu g}{g} d w\right)-1.673
\end{aligned}
$$

To convert $\mathrm{THg}$ concentrations in eggs into equivalent $\mathrm{THg}$ concentrations in blood, the following equation (eq. 5) from Ackerman et al. (2016a), that was developed using 83 females and their full clutches for 3 species with a broad range of tissue $\mathrm{THg}$ concentrations, was used:

$$
\text { (eq. 5; } \left.R^{2}=0.95\right): \ln \left(\text { Female Bird Blood THg } \frac{\mu g}{g} w w\right)=1.0734 \times \ln \left(\text { Egg THg } \frac{\mu g}{g} f w w\right)+0.8149
$$

These tissue conversion equations (1-5) were developed for multiple species and used the largest sample sizes currently available, and therefore represent the best available conversion 
equations for multiple species. However, these equations were developed for four species in the order Charadriiformes and may not be representative of all bird species.

\subsection{Statistical analysis}

Linear mixed-effects models were used to examine factors influencing blood-equivalent $\mathrm{THg}$ concentrations in birds. Separate analyses were conducted for the two types of datasets: original raw data and the literature-review data. This separation ensured that data were not pseudoreplicated within the analyses because some of the original raw datasets were used to publish journal articles and reports that were summarized in the literature review dataset. $\mathrm{THg}$ concentrations in birds were $\log _{\mathrm{e}}$-transformed (natural log denoted as $\ln$ in equations) to improve normality. Back-transformed least squares means are reported with standard errors that were estimated using the delta method (Seber, 1982).

For the original raw dataset, $\log _{\mathrm{e}}$-transformed blood-equivalent $\mathrm{THg}$ concentration was the dependent variable; foraging guild (9 guilds), habitat ( 8 habitats), and ecoregion (11 ecoregions) were fixed factors; and grid cell (432 grid cells each $100 \mathrm{~km} \times 100 \mathrm{~km})$, year (29 years: 1982-2015), and species (225 species) were random factors. To compare $\mathrm{THg}$ concentrations among species without the inclusion of habitat and foraging guild, a separate analysis was conducted where $\log _{\mathrm{e}}$-transformed blood-equivalent $\mathrm{THg}$ concentration was the dependent variable; species was a fixed factor; and grid and year were random factors. To examine the spatial distribution of $\mathrm{THg}$ in birds without the inclusion of habitat and foraging guild, an additional analysis was conducted where $\log _{\mathrm{e}}$-transformed blood-equivalent $\mathrm{THg}$ concentration was the dependent variable; grid was a fixed factor; and species and year were random factors. This same analysis was repeated for each guild with sample sizes $>5000$ (within a guild) to specifically examine the distribution of THg in birds in the piscivore $(n=10243)$, insectivore $(n=8464)$, and omnivore $(n=6685)$ guilds.

For the literature-review dataset, $\log _{\mathrm{e}}$-transformed mean blood-equivalent $\mathrm{THg}$ concentration was the dependent variable; foraging guild ( 8 guilds), habitat ( 8 habitats), and ecoregion (15 ecoregions) were fixed factors; and grid cell (313 grid cells), year (46 years: 19682013), and species (176 species) were random factors. For this analysis, blood-equivalent mean THg concentrations were weighted by the square-root of the study's effective sample size (i.e., the number of individuals used to estimate the mean), which placed more emphasis on the mean estimates that were derived from larger sample sizes. To compare mean $\mathrm{THg}$ concentrations among species without the inclusion of habitat and foraging guild, an analysis was conducted where $\log _{\mathrm{e}}$-transformed mean blood-equivalent $\mathrm{THg}$ concentration was the dependent variable; species was a fixed factor; and grid and year were random factors. To examine the distribution of mean THg concentrations in birds without the inclusion of habitat and foraging guild, an additional analysis was conducted where $\log _{\mathrm{e}}$-transformed mean blood-equivalent $\mathrm{THg}$ concentration was the dependent variable; grid was a fixed factor; and species and year were random factors.

\subsection{Literature review of mercury toxicity to birds and translation of toxicity benchmarks into a common blood-equivalent tissue}

A thorough literature review was conducted and published toxicity benchmarks for all bird tissues were summarized (Table 1). These toxicity benchmarks were then integrated across avian tissues and life-stages into a single toxicity benchmark based on blood-equivalent $\mathrm{THg}$ 
concentrations. To do so, equations and assumptions noted in Table 1's footnotes were used to convert each of the toxicity benchmarks in various tissues into blood-equivalent $\mathrm{THg}$ concentrations. These equations and assumptions are described in more detail in section 2.5.

\section{Results \& Discussion}

Original, raw data on $\mathrm{THg}$ concentrations in 29219 samples were obtained for 225 bird species. Most of the available data were for eggs (69\%), followed by blood (16\%), liver (7\%), feathers $(3 \%)$, kidney (3\%), and muscle (2\%). For most analyses, 1590 data points that were derived from the same bird, but in a different tissue, were excluded yielding a final sample size of 27629 birds. THg concentrations are summarized by species and tissues in Tables S2-S8. From the literature, 1712 mean THg concentrations were obtained for 176 bird species, representing 19998 individuals, from 200 publications (Supplementary Material: References). Figure 1a displays the distribution of THg concentrations using the original, raw data and Figure 1b displays the distribution of mean $\mathrm{THg}$ concentrations using data from the literature review.

\subsection{Factors influencing bird mercury: original raw data}

Bird blood-equivalent $\mathrm{THg}$ concentrations differed among foraging guilds $\left(F_{8,192.3}=11.72\right.$, $p<0.0001$; Figure 2a) and habitat types $\left(F_{7,349.1}=12.69, p<0.0001\right.$; Figure 2b), but did not differ among ecoregions $\left(F_{10,949.1}=0.93, p=0.50\right)$. Piscivores $(0.33 \pm 0.05 \mu \mathrm{g} / \mathrm{g} \mathrm{ww})$ and carnivores $(0.32 \pm 0.10 \mu \mathrm{g} / \mathrm{g} \mathrm{ww})$ exhibited the greatest blood-equivalent least squares mean $\mathrm{THg}$ concentrations, whereas herbivores $(0.03 \pm 0.01 \mu \mathrm{g} / \mathrm{g} \mathrm{ww})$ and granivores $(0.02 \pm 0.01 \mu \mathrm{g} / \mathrm{g} \mathrm{ww})$ exhibited the lowest blood-equivalent least squares mean $\mathrm{THg}$ concentrations. These results are consistent with other studies that have found that birds foraging at higher trophic levels often have higher THg concentrations due to the biomagnification of methylmercury through food chains (Anderson et al., 2009; Blévin et al., 2013). In contrast, birds foraging on plants and seeds at the base of the food chain had substantially lower THg concentrations. Although these results were expected based on the ability of methylmercury to biomagnify, this is the first study to demonstrate differences in THg concentrations among such a wide range of foraging guilds.

Bird blood-equivalent least squares mean $\mathrm{THg}$ concentrations were greatest in ocean $(0.49 \pm 0.22 \mu \mathrm{g} / \mathrm{g} \mathrm{ww})$ and salt marsh $(0.31 \pm 0.07 \mu \mathrm{g} / \mathrm{g} \mathrm{ww})$ habitats and lowest in terrestrialground habitats $(0.04 \pm 0.01 \mu \mathrm{g} / \mathrm{g}$ ww; Figure $2 \mathbf{b})$. Aquatic environments have biogeochemical conditions that are more conducive to methylation and methylmercury is more prevalent in aquatic than terrestrial ecosystems (Ullrich et al., 2001); therefore, it was not surprising that $\mathrm{THg}$ concentrations in birds would be lower in terrestrial than aquatic environments. However, some terrestrial birds can receive substantial aquatic subsidies of methylmercury through emergent aquatic insects and the associated food web (Cristol et al., 2008; Jackson et al., 2011b), so some terrestrial species can be exposed to higher methylmercury levels than would be assumed based upon their terrestrial foraging habits. Ocean and estuary environments tended to have birds with higher THg concentrations than those in freshwater environments. This difference could be due to several mechanisms, including differences in bioavailable methylmercury (such as differences in biogeochemical conditions, inorganic mercury availability, and methylmercury production; Ullrich et al., 2001), generally more complex food web structures and longer food-chain lengths in oceans and estuaries compared to smaller freshwater ecosystems (Post, 2002), or the ecology of bird species in these different habitats. 
Blood-equivalent THg concentrations also differed among bird species $\left(F_{224,22076}=130.79\right.$, $p<0.0001$; Figure 3; Figures S1-S7; Table S8). In particular, Forster's terns had the highest least squares mean blood-equivalent $\mathrm{THg}$ concentrations of any species with sample sizes $\geq 60$ (Figure 3), which is the approximate sample size necessary to estimate a population's mean $\mathrm{THg}$ concentration with 10\% accuracy (Ackerman et al., 2016b). Blood-equivalent geometric mean $\mathrm{THg}$ concentrations were $2.35 \mu \mathrm{g} / \mathrm{g}$ ww in Forster's terns $\left(5^{\text {th }}\right.$ to $95^{\text {th }}$ percentile: $0.87-6.39 \mu \mathrm{g} / \mathrm{g}$ ww; Table S8). For comparison, common loons in the west, another piscivore that is well studied throughout North America, had a blood-equivalent geometric mean $\mathrm{THg}$ concentration of $0.89 \mu \mathrm{g} / \mathrm{g}$ ww $\left(5^{\text {th }}\right.$ to $95^{\text {th }}$ percentile: $0.25-3.90 \mu \mathrm{g} / \mathrm{g}$ ww; Table S8). Some other species with notably high blood-equivalent geometric mean $\mathrm{THg}$ concentrations were pigeon guillemots $(2.08$ $\mu \mathrm{g} / \mathrm{g} w \mathrm{w})$, Caspian terns $(1.58 \mu \mathrm{g} / \mathrm{g} w \mathrm{w})$, least terns $(1.15 \mu \mathrm{g} / \mathrm{g} \mathrm{ww})$, black skimmers $(0.90 \mu \mathrm{g} / \mathrm{g}$ ww), Clark's grebes $(0.83 \mu \mathrm{g} / \mathrm{g} w w)$, and black-necked stilts $(0.79 \mu \mathrm{g} / \mathrm{g} \mathrm{ww}$; Table S8).

Blood-equivalent $\mathrm{THg}$ concentrations of individual birds were above common toxicity benchmarks (Table 1) in many areas throughout western North America (Figure 1a). In particular, multiple individuals exhibited $\mathrm{THg}$ concentrations above $3.0 \mu \mathrm{g} / \mathrm{g}$ ww in San Francisco Bay, California; Central Valley, California; Carson River watershed, Nevada; Great Salt Lake, Utah; northeastern Washington; northeastern Montana; multiple sites along the Missouri River; southern Arizona; the Gulf Coast of Texas; Alaska's North Slope; and the Aleutian Archipelago. These individuals typically were from species belonging to upper trophic level guilds, such as piscivores and carnivores.

To examine spatial variation in mercury exposure of birds that accounted for differences in $\mathrm{THg}$ concentrations among species, the distribution of blood-equivalent $\mathrm{THg}$ concentrations in birds also were mapped using model-estimated least squares means within $100-\mathrm{km} \times 100-\mathrm{km}$ grid cells across western North America. As expected, bird blood-equivalent THg concentrations differed among grid cells $\left(F_{431,26126}=20.67, p<0.0001\right.$; Figure 4a). Modelestimated mean $\mathrm{THg}$ concentrations were greatest in coastal California, western Nevada, and Alaska's North Slope (Figure 4a). Other apparent hotspots, such as those in other parts of Alaska, British Columbia, Hawaiian Islands, and the western contiguous United States, had high THg concentrations but low sample sizes (typically $<15$; Figure $4 \mathbf{b}$ ) and high coefficients of variation ( $>25 \%$; Figure 4c) making interpretation at these sites more difficult. The analysis was repeated separately for each guild with a sample size $>5000$ and similar results were generally found for the piscivore (Figure 5a), insectivore (Figure 5b), and omnivore guilds (Figure 5c). THg concentrations were compared among guilds when they overlapped in the same grid cell. The strength of the correlations between guild-specific least squares mean blood-equivalent $\mathrm{THg}$ concentrations within grid cells varied among guilds, although the relationships were always positive (Pearson correlations; omnivore vs insectivore: $n=79$ grid cells, $r=0.47, p<0.0001$; omnivore vs piscivore: $n=56$ grid cells, $r=0.24, p=0.08$; piscivore vs insectivore: $n=69$ grid cells, $r=0.16, p=0.19)$.

\subsection{Factors influencing bird mercury: literature review}

Bird blood-equivalent least squares mean $\mathrm{THg}$ concentrations differed among foraging guilds $\left(F_{7,167.1}=16.01, p<0.0001\right.$; Figure 2a), habitat types $\left(F_{7,211}=2.86, p=0.01\right.$; Figure 2b), and ecoregions $\left(F_{14,283.3}=2.08, p=0.01\right.$; Figure 6). Carnivores $(0.37 \pm 0.15 \mu \mathrm{g} / \mathrm{g} \mathrm{ww})$ and piscivores $(0.31 \pm 0.09 \mu \mathrm{g} / \mathrm{g} \mathrm{ww})$ exhibited the greatest blood-equivalent least squares mean $\mathrm{THg}$ concentrations, whereas herbivores $(0.01 \pm 0.01 \mu \mathrm{g} / \mathrm{g}$ ww $)$ exhibited the lowest blood-equivalent 
least squares mean THg concentrations. As observed in the raw dataset, bird blood-equivalent least squares mean $\mathrm{THg}$ concentrations were highest in salt marsh $(0.35 \pm 0.28 \mu \mathrm{g} / \mathrm{g} \mathrm{ww})$ and ocean $(0.23 \pm 0.08 \mu \mathrm{g} / \mathrm{g} \mathrm{ww})$ habitats and lowest in terrestrial-ground habitats $(0.04 \pm 0.01 \mu \mathrm{g} / \mathrm{g}$ $\mathrm{ww})$. Among ecoregions, bird blood-equivalent least squares mean $\mathrm{THg}$ concentrations were greatest in tropical dry forests $(0.22 \pm 0.13 \mu \mathrm{g} / \mathrm{g} \mathrm{ww})$ and tundra habitats $(0.22 \pm 0.06 \mu \mathrm{g} / \mathrm{g} \mathrm{ww})$ and lowest in temperate Sierras $(0.06 \pm 0.03 \mu \mathrm{g} / \mathrm{g} \mathrm{ww})$ and southern semi-arid highlands $(0.04 \pm 0.02 \mu \mathrm{g} / \mathrm{g} \mathrm{ww})$, but pair-wise comparisons suggested few statistically significant differences among ecoregions (Figure 6).

Similar to the raw dataset, bird blood-equivalent mean $\mathrm{THg}$ concentrations differed among species $\left(F_{177,1427}=10.61, p<0.0001\right.$; Figures S8-S14 $)$ and grid cells $\left(F_{312,1195}=4.17\right.$, $p<0.0001$; Figure 7a). Model-estimated mean bird THg concentrations based on the literature data also were highest in central and coastal California, western Nevada, Alaska's North Slope, and the Aleutian Islands (Figure 7a). Additional hotspots were present throughout the west, although several of these additional sites had low sample sizes (typically <15; Figure 7b) and high coefficients of variation (>25\%; Figure 7c). To directly compare the raw data (432 grid cells) to the literature data (313 grid cells), model-estimated mean bird $\mathrm{THg}$ concentrations within the 165 grid cells $\left(100 \mathrm{~km}^{2}\right)$ that contained both raw data and literature-review data were correlated. Least squares mean blood-equivalent $\mathrm{THg}$ concentrations were positively correlated between the two separate datasets, although the strength of the correlation was moderate (Pearson correlation; $r=0.34 ; p<0.0001$ ).

\subsection{Hotspots of bird mercury contamination in western North America}

From the raw and literature-review data analyses, hotspots were identified in western North America for mercury contamination in birds. Several of these identified hotspots were common to both the raw and literature-review datasets, including the western Aleutian Islands, Alaska's North Slope, Great Basin (especially western Nevada), and San Francisco Bay and Central Valley of California (Figures 4 and 7). To facilitate visualization of avian mercury exposure risk across western North America, a comprehensive map (Figure 8) was produced by combining the maps developed from the raw data and the literature-review data. When a grid cell contained $\mathrm{THg}$ concentration estimates from both analyses, priority was given to the estimate derived from the raw data and excluded the literature review-derived estimate for that grid cell. All grid cells that contained least squares mean blood-equivalent $\mathrm{THg}$ concentrations that were above the $80^{\text {th }}$ percentile of the entire dataset were considered to be potential hotspots for bird mercury contamination. Using this approach, 101 grid cells were identified that can be considered to be hotspots for avian mercury contamination in western North America (red grid cells in Figure 8). These hotspots included locations in the Aleutian Islands; the North Slope of Alaska; east-central Alaska; southeastern Alaska; northern Nunavut, Canada; Puget Sound, Washington; Great Basin (especially northern Idaho, and western and northern Nevada); San Francisco Bay and Central Valley, California; southern Arizona; the Gulf Coast of Texas; and the Hawaiian Islands (Figure 8).

Among the grid cell hotspots identified from the combination of the raw and literaturereview datasets, many were characterized by low sample sizes ( $<15$ samples; $n=1$ grid cell), high coefficients of variation ( $>25 \% ; n=7$ grid cells), or both ( $n=71$ grid cells). Thus, additional sampling in these locations would help to determine if they are hotspots for bird mercury contamination. On the other hand, 22 of the identified hotspots were well sampled $(>15$ 
samples) and had relatively low coefficients of variation $(<25 \%)$. These identified hotspots (red grid cells with bolded black borders in Figure 8) included the North Slope of Alaska; the western Aleutian Islands; Puget Sound; southwestern Idaho; western Wyoming; northern Montana; North Dakota and South Dakota along the Missouri River; central Arizona; the Gulf Coast of Texas; western Nevada; and San Francisco Bay, California. Similar hotspots of mercury contamination were observed at some sites for freshwater fishes, especially in western and northern Nevada and central Arizona (Eagles-Smith et al., submitted to this issue). Avian mercury hotspots on the North Slope of Alaska may reflect recent trends in increased mercury exposure observed in piscivorous birds in the Arctic (Evers et al., 2014; Rigét et al., 2011), which are thought to be related to atmospheric deposition (Blum et al., 2013; Sunderland et al., 2009) and warmer Arctic temperatures associated with climate change potentially releasing inorganic mercury within snowpack, permafrost, and sea ice, and enhancing methylmercury production (AMAP, 2002; Brooks et al., 2006). In the Aleutian Islands, several studies have demonstrated high $\mathrm{THg}$ concentrations in birds with concentrations sometimes increasing westward across the island chain (Anthony et al., 2007; Ricca et al., 2008). In Washington's Puget Sound, surf scoters exhibited THg concentrations similar to those of surf scoters in San Francisco Bay, California (Henny et al., 1991; Ohlendorf et al., 1987) and mercury concentrations of both surf scoters and western grebes increased as they over-wintered in Puget Sound (Henny et al., 1991, 1990). The hotspot in the Gulf Coast of Texas included Lavaca Bay, a designated mercury superfund site. Finally, San Francisco Bay estuary, California and western Nevada, have a long history of mercury contamination due to the legacy of mining (Conaway et al., 2008; Singer et al., 2013) and have widespread mercury contamination of biota (Ackerman et al., 2008, 2007; Eagles-Smith and Ackerman, 2014; Eagles-Smith et al., 2009a; Henny et al., 2007, 2002). San Francisco Bay, California; western Nevada; and other Great Basin areas are of particular concern for methylmercury exposure to birds in western North America, and would benefit from inclusion in continental contaminant monitoring programs (Mason et al., 2005).

\subsection{Literature review of mercury toxicity to birds and translation of toxicity benchmarks into a common blood-equivalent tissue}

The literature was reviewed, the published toxicity benchmarks for birds were summarized, and toxicity benchmarks for different tissues were integrated into a common bloodequivalent $\mathrm{THg}$ concentration (Table 1). This approach provides the ability to integrate toxicity risk across avian tissues and life-stages into a single toxicity benchmark based on bird blood. Effects occurred across a range of blood-equivalent $\mathrm{THg}$ concentrations, with many documented effects in the range of 1.0 to $3.0 \mu \mathrm{g} / \mathrm{g} \mathrm{ww}$ and more severe effects occurring over $3.0 \mu \mathrm{g} / \mathrm{g} \mathrm{ww}$ (Table 1). The lowest documented effects in birds occurred at a blood-equivalent $\mathrm{THg}$ concentration of $0.2 \mu \mathrm{g} / \mathrm{g}$ ww (Table 1). In general, health, physiology, behavior, and reproduction tended to be affected by methylmercury at lower blood-equivalent $\mathrm{THg}$ concentrations $(1.0 \mu \mathrm{g} / \mathrm{g} \mathrm{ww})$, substantial impairment to health and reproduction occurred at moderate blood-equivalent $\mathrm{THg}$ concentrations $(2.0 \mu \mathrm{g} / \mathrm{g} \mathrm{ww})$, more severe impairment to health and reproduction occurred at higher blood-equivalent THg concentrations $(3.0 \mu \mathrm{g} / \mathrm{g} \mathrm{ww})$, and often complete reproductive failure occurred at extremely high blood-equivalent $\mathrm{THg}$ concentrations $(4.0 \mu \mathrm{g} / \mathrm{g} \mathrm{ww}$; Table 1). THg concentrations in blood over $4.0 \mu \mathrm{g} / \mathrm{g}$ ww in bird blood resulted in a variety of severe physiological and reproductive effects, including adult mortality at blood-equivalent $\mathrm{THg}$ concentrations over $8.5 \mu \mathrm{g} / \mathrm{g}$ ww (Table 1). 
At approximately $1.0 \mu \mathrm{g} / \mathrm{g}$ ww in bird blood, effects of methylmercury exposure included altered bird breeding behaviors (Frederick and Jayasena, 2010; Tartu et al., 2015); reduced breeding success of south polar skuas during the subsequent breeding season (Goutte et al., 2014); reduced egg hatchability ( $\mathrm{LC}_{50}$ : lethal concentration where $50 \%$ mortality occurs) of highly-sensitive birds (Heinz et al., 2009b); an estimated 12\% reduction in common loon productivity (Burgess and Meyer, 2008); reduced egg hatchability $\left(\mathrm{LC}_{50}\right)$ in thick-billed murres (Braune et al., 2012); the onset of demethylation of methymercury in the liver of Forster's terns, Caspian terns, American avocets, and black-necked stilts (Eagles-Smith et al., 2009b); changes to enzymes associated with glutathione metabolism and antioxidant activity in ruddy ducks (Hoffman et al., 1998); and impaired behavior of common loons (Depew et al., 2012). A bird blood-equivalent $\mathrm{THg}$ concentration of $1.0 \mu \mathrm{g} / \mathrm{g} \mathrm{ww}$ also is very close to the derived toxicity benchmark for impaired bird reproduction using egg and liver tissue in the review by Shore et al. (2011). At approximately $2.0 \mu \mathrm{g} / \mathrm{g} \mathrm{ww}$ in bird blood, effects of methylmercury exposure included impaired reproduction in captive dosed mallards (Heinz, 1979); reduced egg hatchability $\left(\mathrm{LC}_{50}\right)$ of moderately-sensitive birds (Heinz et al., 2009b); reduced breeding success of brown skuas during the subsequent breeding season (Goutte et al., 2014); an estimated 23\% reduction in common loon productivity (Burgess and Meyer, 2008); reduced egg hatchability $\left(\mathrm{LC}_{50}\right.$ ) in Arctic terns (Braune et al., 2012); and impaired productivity of common loons (Depew et al., 2012). At approximately $3.0 \mu \mathrm{g} / \mathrm{g}$ ww in bird blood, effects of methylmercury exposure included impaired productivity (Barr, 1986), reproductive failure (Depew et al., 2012; Evers et al., 2008), and a 35\% reduction in the productivity of common loons (Burgess and Meyer, 2008); decreased immune competence in tree swallows (Hawley et al., 2009); and decreased egg hatchability in ring-necked pheasants (Fimreite, 1971). Finally, at approximately $4.0 \mu \mathrm{g} / \mathrm{g} \mathrm{ww}$ in bird blood, effects of methylmercury exposure became widespread among most bird species and included reduced egg hatchability $\left(\mathrm{LC}_{50}\right)$ of birds that are less-sensitive to methylmercury toxicity (Heinz et al., 2009b); reduced egg hatchability $\left(\mathrm{LC}_{50}\right)$ in common loons (Kenow et al., 2011); increased incidence of same-sex pairs (Frederick and Jayasena, 2010); and an estimated $50 \%$ reduction in common loon productivity (Burgess and Meyer, 2008).

Because sensitivity to methylmercury toxicity can differ widely among species (Heinz et al., 2009b), it is difficult to select a single toxicity benchmark that can be applied across species, such as for the 273 species included in this paper (Table S1). However, some general principles can be derived from the synthesis of published toxicity studies that can be used to guide the interpretation of bird methylmercury concentrations (Table 1). In general, birds with blood $\mathrm{THg}$ concentrations $<0.2 \mu \mathrm{g} / \mathrm{g}$ ww are below any known effect levels and can be considered to have background levels of methylmercury exposure. Birds with blood THg concentrations between $0.2-1.0 \mu \mathrm{g} / \mathrm{g}$ ww can be considered to have lower risk, $1.0-3.0 \mu \mathrm{g} / \mathrm{g}$ ww have moderate risk, 3.0$4.0 \mu \mathrm{g} / \mathrm{g}$ ww have higher risk, and $>4.0 \mu \mathrm{g} / \mathrm{g}$ ww have severe risk to methylmercury toxicity. Overall, $66 \%$ of individual birds exceeded a blood-equivalent $\mathrm{THg}$ concentration of $0.2 \mu \mathrm{g} / \mathrm{g} \mathrm{ww}$ (above background levels), 28\% exceeded $1.0 \mu \mathrm{g} / \mathrm{g}$ ww (moderate risk and above), $8 \%$ exceeded $3.0 \mu \mathrm{g} / \mathrm{g}$ ww (high risk and above), and $4 \%$ exceeded $4.0 \mu \mathrm{g} / \mathrm{g}$ ww (severe risk; Table S9). Because numerous effects to health and reproduction occur in many bird species at blood $\mathrm{THg}$ concentrations near $3.0 \mu \mathrm{g} / \mathrm{g}$ ww (Table 1), that is a useful methylmercury toxicity benchmark for the potential for more severe impairment to bird health and reproduction. Species with $>5 \%$ of individuals exceeding $\mathrm{THg}$ concentrations of $3.0 \mu \mathrm{g} / \mathrm{g}$ ww in blood included horned grebe (100\%), black-footed albatross (44\%), Forster's tern (33\%), pigeon guillemot (30\%), willet 
(25\%), northern fulmar (23\%), northern shoveler (19\%), black skimmer (13\%), Clark's grebe (11\%), clapper rail (11\%), American white pelican (11\%), Caspian tern (10\%), peregrine falcon $(9 \%)$, least tern $(9 \%)$, common loon $(8 \%)$, double-crested cormorant $(8 \%)$, black-necked stilt (8\%), Wilson's phalarope (8\%), snowy plover (7\%), and ruddy turnstone (7\%; Table S9). Songbirds, in particular, may be more sensitive to methylmercury toxicity (Heinz et al., 2009b), and substantial impairment may occur at blood $\mathrm{THg}$ concentrations of only $1.0 \mu \mathrm{g} / \mathrm{g} \mathrm{ww}$ (Table 1). The percentage of individual songbirds exceeding $1.0 \mu \mathrm{g} / \mathrm{g}$ ww included western kingbird (40\%), bank swallow (20\%), American robin (10\%), yellow-breasted chat (7\%), ash-throated flycatcher $(4 \%)$, willow flycatcher $(4 \%)$, tree swallow (3\%), house wren $(2 \%)$, rusty blackbird (2\%), white-crowned sparrow (2\%), and barn swallow (1\%; Table S9). Table S9 can be used to examine additional species at a range of blood-equivalent $\mathrm{THg}$ concentrations from 0.2 to 4.0 $\mu \mathrm{g} / \mathrm{g} \mathrm{ww}$. Figure 9 shows the proportion of individual birds exceeding various toxicity benchmarks only for those species with $\geq 60$ samples. Often, there can be as much variability in $\mathrm{THg}$ concentrations among individuals of the same species as among species due to the substantially large influences of local site and habitat-specific effects on methylmercury production and bioaccumulation (Eagles-Smith et al., 2009a); therefore comparisons among species (Figures S2-S14) should be viewed as approximations of relative methylmercury exposure at this large scale of study.

\section{Suggestions for mercury monitoring programs}

To compile mercury contamination data in birds throughout western North America, many different datasets derived from seven different tissues (egg, albumen, whole blood, muscle, liver, kidney, and feathers) were used. It was necessary to make several assumptions and to use general equations to translate these seven tissues into a common matrix $\square$ blood-equivalent THg concentrations $\square$ for comparisons among studies and species. These generalities introduced uncertainty into the resulting estimates of blood-equivalent $\mathrm{THg}$ concentrations, especially for tissues like adult feathers. These results suggest that future mercury monitoring efforts would benefit from sampling tissues that are most-easily translated into a tissue that has a well-developed toxicity benchmark and that is directly relevant to bird reproduction (Table 2). These high-priority sampling tissues include adult blood, eggs, and chick down feathers (in contrast to low-priority adult feathers). Bird THg concentrations in whole blood are highly correlated to $\mathrm{THg}$ and methylmercury concentrations in internal tissues that require more invasive sampling procedures (Eagles-Smith et al., 2008). Additionally, the THg concentration in a female's blood is highly correlated to THg concentrations in her eggs (Ackerman et al., 2016a), providing THg concentrations in blood with a strong link to the numerous toxicity benchmarks that have been developed for egg hatchability. Eggs are a high-priority sampling tissue because they are relatively easy to sample, and relate directly to many toxicity benchmarks, including impaired reproduction. Egg THg concentrations need to be reported on a fresh wet weight basis (Ackerman et al., 2013; Stickel et al., 1973), and therefore it is necessary to collect additional egg morphometric data (such as egg length, width, and weight) for proper adjustments to the measured egg THg concentrations. Down feathers also can be a useful tissue, because $\mathrm{THg}$ concentrations in down feathers represent in ovo exposure and can be translated into equivalent THg concentrations in whole eggs (Ackerman and Eagles-Smith, 2009). Besides chick down feathers, sampling juvenile birds for contaminant monitoring purposes is not advised, because THg concentrations in internal tissues (including blood) change rapidly as 
chicks age due to mass dilution and mercury transfer into growing feathers (Ackerman et al., 2011; Kenow et al., 2007) and, therefore, are difficult to interpret.

Tissues which have a moderate-priority for assessing bird contamination include egg albumen, that can be non-lethally sampled and translated into whole-egg THg concentrations (Ackerman and Eagles-Smith, 2009; Stebbins et al., 2009); and muscle, liver, kidney, and brain, which are highly correlated to other internal tissues, including whole blood (Eagles-Smith et al., 2008; Scheuhammer et al., 2008), but require more invasive sampling procedures. Additionally, unlike in blood, eggs, muscle, and feathers, most of the THg in the liver and kidney often is not in the methylmercury form due to the ability of birds to demethylate methylmercury within the liver, especially at high THg concentrations (Eagles-Smith et al., 2009b; Henny et al., 2002; Scheuhammer et al., 2008). Therefore, chemical determination of methylmercury, in addition to $\mathrm{THg}$, may be necessary when using liver and kidney tissues. Finally, although many mercury monitoring programs use them, feathers have low-priority as a preferred tissue for sampling. Feather THg concentrations are highly variable within an individual bird (Bond and Diamond, 2008; Braune and Gaskin, 1987; Cristol et al., 2012; Furness et al., 1986), and are relatively poorly correlated with THg concentrations in internal tissues (Eagles-Smith et al., 2008; Evers et al., 1998) that are more likely to indicate risk of current methylmercury toxicity. Furthermore, $\mathrm{THg}$ concentrations in feathers represent $\mathrm{THg}$ concentrations in blood at the time of feather growth, which is a combination of the bird's body burden of mercury, via redistribution of mercury among internal tissues during molt, and recent mercury acquired through diet (Braune and Gaskin, 1987; Furness et al., 1986; Thompson et al., 1998). Not only is the timing of feather molt often unknown, but molt may represent a time when internal mercury concentrations are rapidly changing due to mercury transfer to feathers (Ackerman et al., 2011; Condon and Cristol, 2009) and the often-associated nutritional stress. There are certainly exceptions where adult feathers may be useful for mercury monitoring, including (1) for non-migratory bird species with extremely small home ranges (or other ecology) which make $\mathrm{THg}$ concentrations in feathers highly correlated to those in internal tissues (Ackerman et al., 2012), (2) when more invasive sampling methods need to be avoided (such as endangered species), or (3) when using museum specimens to examine long-term temporal trends, because no other tissue is available (Bond et al., 2015; Monteiro and Furness, 1997).

In addition to selecting the most useful bird tissues, reasonable efforts to ensure adequate sample sizes are acquired are important for properly characterizing methylmercury risk to birds. Few studies have been published on this topic, but Ackerman et al. (2016b) demonstrated that to estimate a population's mean THg concentration using eggs would typically require $>60$ samples to be within $10 \%$ of the population's actual mean $\mathrm{THg}$ concentration. Similar sample sizes would be necessary for other bird populations when variance in $\mathrm{THg}$ concentrations is comparable to any of the three species in that study. Sampling fewer individuals will result in an estimate that has lower accuracy, but sampling 15-30 individuals will normally provide an estimate within $20 \%$ of the population's actual mean THg concentration (Ackerman et al., 2016b).

\section{Acknowledgments}

This work was conducted as a part of the Western North American Mercury Synthesis Working Group supported by the John Wesley Powell Center for Analysis and Synthesis, funded by the U.S. Geological Survey with additional support from the U.S. Geological Survey's 
Ecosystems Mission Area and Contaminant Biology Program. We thank the U.S. Fish and Wildlife Service's Environmental Contaminants Data Management System (ECDMS) managed by staff at the Analytical Control Facility, and the hundreds of scientists which have contributed to the ECDMS and STAMP datasets. We thank Charles Henny of U.S. Geological Survey for access to osprey data. We also thank Sarah Lemelin, Laura Young, Michelle Boyles, and Branden Johnson for help with data compilation; Michelle Lutz and Michael Tate for GIS layers; and Julie Yee for statistical advice. The use of trade, product, or firm names in the publication is for descriptive purposes only and does not imply endorsement by the U.S. Government.

\section{References}

References Cited in Table 1

(Ackerman et al., 2016a, 2015, 2012; Albers et al., 2007; Barr, 1986; Bennett et al., 2009; Brasso and Cristol, 2008; Braune et al., 2012; Burgess and Meyer, 2008; Carlson et al., 2014; Custer et al., 2000; Depew et al., 2012; Eagles-Smith et al., 2009b, 2008; Evers et al., 2008; Fallacara et al., 2011; Fimreite and Karstad, 1971; Fimreite, 1974, 1971; Finkelstein et al., 2007; Finley and Stendell, 1978; Finley et al., 1979; Franceschini et al., 2009; Frederick and Jayasena, 2010; Gibson et al., 2014; Goutte et al., 2014; Hallinger and Cristol, 2011; Hawley et al., 2009; Heinz, 1979; Heinz et al., 2009a; Henny et al., 2002; Herring et al., 2010; Hoffman and Heinz, 1998; Hoffman et al., 2011, 1998; Jackson et al., 2011a; Kenow et al., 2011; Kobiela et al., 2015; Moore et al., 2014; Newton and Haas, 1988; Scheuhammer, 1988; Scheuhammer et al., 2008, 2007; Shore et al., 2011; Spann et al., 1972; S Tartu et al., 2015; Sabrina Tartu et al., 2015; Tartu et al., 2013; Thompson, 1996; Varian-Ramos et al., 2014; Zillioux et al., 1993)

\section{References Cited in Table 2}

(Ackerman and Eagles-Smith, 2009; Ackerman et al., 2016a, 2013, 2012, 2011; Bond and Diamond, 2009; Brasso and Cristol, 2008; Brasso et al., 2010; Braune and Gaskin, 1987; Braune, 1987; Dauwe et al., 2003; Eagles-Smith et al., 2009b, 2008; Evers et al., 2003; Finley and Stendell, 1978; Furness et al., 1986; Heinz et al., 2010; Henny et al., 2002; Jackson et al., 2011a; Kennamer et al., 2005; Kenow et al., 2015, 2011, 2007; Ou et al., 2015; Rimmer et al., 2005; Scheuhammer et al., 1998, 2008; Stebbins et al., 2009; D. Thompson and Furness, 1989)

\section{References}

Ackerman, J.T., Eagles-Smith, C.A., 2009. Integrating toxicity risk in bird eggs and chicks: using chick down feathers to estimate mercury concentrations in eggs. Environ. Sci. Technol. 43, 2166-2172.

Ackerman, J.T., Eagles-Smith, C.A., Herzog, M.P., 2011. Bird mercury concentrations change rapidly as chicks age: toxicological risk is highest at hatching and fledging. Environ. Sci. Technol. 45, 5418-5425. doi:10.1021/es200647g 
Ackerman, J.T., Eagles-Smith, C.A., Herzog, M.P., Hartman, C.A., 2016a. Maternal transfer of contaminants in birds: mercury and selenium concentrations in parents and their eggs. Environ. Pollut. 210, 145-154.

Ackerman, J.T., Eagles-Smith, C.A., Herzog, M.P., Yee, J.L., Hartman, C.A., 2016b. Egg laying sequence influences egg mercury concentrations and egg size in three bird species: implications for contaminant monitoring programs. Environ. Toxicol. Chem. (In Press.

Ackerman, J.T., Eagles-Smith, C.A., Takekawa, J.Y., Bluso, J.D., Adelsbach, T.L., 2008. Mercury concentrations in blood and feathers of prebreeding Forster's terns in relation to space use of San Francisco Bay, California, USA, habitats. Environ. Toxicol. Chem. 27, 897-908. doi:Doi 10.1897/07-230.1

Ackerman, J.T., Eagles-Smith, C.A., Takekawa, J.Y., Demers, S.A., Adelsbach, T.L., Bluso, J.D., Miles, A.K., Warnock, N., Suchanek, T.H., Schwarzbach, S.E., 2007. Mercury concentrations and space use of pre-breeding American avocets and black-necked stilts in San Francisco Bay. Sci. Total Environ. 384, 452-466. doi:10.1016/j.scitotenv.2007.04.027

Ackerman, J.T., Hartman, C.A., Eagles-Smith, C.A., Herzog, M.P., Davis, J.A., Ichikawa, G., Bonnema, A., 2015. Estimating mercury exposure of piscivorous birds and sport fish using prey fish monitoring. Environ. Sci. Technol. 49, 13596-13604. doi:10.1021/acs.est.5b02691

Ackerman, J.T., Herzog, M.P., Schwarzbach, S.E., 2013. Methylmercury is the predominant form of mercury in bird eggs: a synthesis. Environ. Sci. Technol. 47, 2052-2060.

Ackerman, J.T., Overton, C.T., Casazza, M.L., Takekawa, J.Y., Eagles-Smith, C.A., Keister, R.A., Herzog, M.P., 2012. Does mercury contamination reduce body condition of endangered California clapper rails? Environ. Pollut. 162, 439-448. doi:10.1016/j.envpol.2011.12.004

Albers, P.H., Koterba, M.T., Rossmann, R., Link, W.A., French, J.B., Bennett, R.S., Bauer, W.C., 2007. Effects of methylmercury on reproduction in American kestrels. Environ. Toxicol. Chem. 26, 1856-1866. doi:10.1897/06-592R.1

AMAP, 2002. Arctic Pollution 2002: Persistent Organic Pollutants, Heavy Metals, Radioactivity, Human Health, Changing Pathways. Oslo, Norway.

Anderson, O., Phillips, R., McDonald, R., Shore, R., McGill, R., Bearhop, S., 2009. Influence of trophic position and foraging range on mercury levels within a seabird community. Mar. Ecol. Prog. Ser. 375, 277-288. doi:10.3354/meps07784

Anthony, R.G., Miles, A.K., Ricca, M.A., Estes, J.A., 2007. Environmental contaminants in bald eagle eggs from the Aleutian Archipelago. Environ. Toxicol. Chem. 26, 1843-1855. doi:10.1897/06-334R.1 
Barr, J.F., 1986. Population dynamics of the common loon (Gavia immer) associated with mercury - contaminated waters in northwestern Ontario, Occasional Paper No. 56. Canadian Wildlife Service, Ottawa.

Bennett, R.S., French, J.B., Rossmann, R., Haebler, R., 2009. Dietary toxicity and tissue accumulation of methylmercury in American kestrels. Arch. Environ. Contam. Toxicol. 56, 149-156. doi:10.1007/s00244-008-9168-8

Blévin, P., Carravieri, A., Jaeger, A., Chastel, O., Bustamante, P., Cherel, Y., 2013. Wide range of mercury contamination in chicks of southern ocean seabirds. PLoS One 8, e54508. doi:10.1371/journal.pone.0054508

Blum, J.D., Popp, B.N., Drazen, J.C., Anela, C.C., Johnson, M.W., 2013. Methylmercury production below the mixed layer in the North Pacific Ocean. Nat. Geosci. 6, 879-884. doi:10.1038/ngeo1918

Bond, A.L., Diamond, A.W., 2009. Total and methyl mercury concentrations in seabird feathers and eggs. Arch. Environ. Contam. Toxicol. 56, 286-291. doi:10.1007/s00244-008-9185-7

Bond, A.L., Diamond, A.W., 2008. High within-individual variation in total mercury concentration in seabird feathers. Environ. Toxicol. Chem. 27, 2375-2377. doi:10.1897/08163.1

Bond, A.L., Hobson, K.A., Branfireun, B.A., 2015. Rapidly increasing methyl mercury in endangered ivory gull (Pagophila eburnea) feathers over a 130 year record. Proc. R. Soc. B 282. doi:10.1098/rspb.2015.0032

Brasso, R.L., Abdel Latif, M.K., Cristol, D.A., 2010. Relationship between laying sequence and mercury concentration in tree swallow eggs. Environ. Toxicol. Chem. 29, 1155-1159. doi:10.1002/etc. 144

Brasso, R.L., Cristol, D.A., 2008. Effects of mercury exposure on the reproductive success of tree swallows (Tachycineta bicolor). Ecotoxicology 17, 133-41. doi:10.1007/s10646-0070163-z

Braune, B., Gaskin, D., 1987. Mercury levels in Bonaparte's gulls (Larus philadelphia) during autumn molt in the Quoddy region, New Brunswick, Canada. Arch. Environ. Contam. Toxicol. 549, 539-549.

Braune, B.M., 1987. Comparison of total mercury levels in relation to diet and molt for 9 species of marine birds. Arch. Environ. Contam. Toxicol. 16, 217-224.

Braune, B.M., Scheuhammer, A.M., Crump, D., Jones, S., Porter, E., Bond, D., 2012. Toxicity of methylmercury injected into eggs of thick-billed murres and arctic terns. Ecotoxicology 21, 2143-52. doi:10.1007/s10646-012-0967-3 
Brooks, S.B., Saiz-Lopez, A., Skov, H., Lindberg, S.E., Plane, J.M.C., Goodsite, M.E., 2006. The mass balance of mercury in the springtime arctic environment. Geophys. Res. Lett. 33, L13812. doi:10.1029/2005GL025525

Burgess, N.M., Meyer, M.W., 2008. Methylmercury exposure associated with reduced productivity in common loons. Ecotoxicology 17, 83-91. doi:10.1007/s10646-007-0167-8

Carlson, J.R., Cristol, D., Swaddle, J.P., 2014. Dietary mercury exposure causes decreased escape takeoff flight performance and increased molt rate in European starlings (Sturnus vulgaris). Ecotoxicology 23, 1464-73. doi:10.1007/s10646-014-1288-5

Commission for Environmental Cooperation, 1997. Ecological regions of North America: toward a common perspective. Montreal, Quebec, Canada.

Conaway, C.H., Black, F.J., Grieb, T.M., Roy, S., Flegal, A.R., 2008. Mercury in the San Francisco Estuary. Rev. Environ. Contam. Toxicol. 194, 29-54. doi:10.1007/978-0-38774816-0_2

Condon, A., Cristol, D., 2009. Feather growth influences blood mercury level of young songbirds. Environ. Toxicol. Chem. 28, 395-401.

Cristol, D. a., Mojica, E.K., Varian-Ramos, C.W., Watts, B.D., 2012. Molted feathers indicate low mercury in bald eagles of the Chesapeake Bay, USA. Ecol. Indic. 18, 20-24. doi:10.1016/j.ecolind.2011.10.007

Cristol, D.A., Brasso, R.L., Condon, A.M., Fovargue, R.E., Friedman, S.L., Hallinger, K.K., Monroe, A.P., White, A.E., 2008. The movement of aquatic mercury through terrestrial food webs. Science 320, 335. doi:10.1126/science.1154082

Custer, T.W., Custer, C.M., Hines, R.K., Sparks, D.W., Melancon, M.J., Hoffman, D.J., Bickham, J.W., Wickliffe, J.K., 2000. Mixed-Function oxygenases, oxidative stress, and chromosomal damage measured in lesser scaup wintering on the Indiana Harbor Canal. Arch. Environ. Contam. Toxicol. 38, 522-529. doi:10.1007/s002449910068

Dauwe, T., Bervoets, L., Pinxten, R., Blust, R., Eens, M., 2003. Variation of heavy metals within and among feathers of birds of prey: effects of molt and external contamination. Environ. Pollut. 124, 429-436. doi:10.1016/S0269-7491(03)00044-7

Day, R.D., Roseneau, D.G., Vander Pol, S.S., Hobson, K.A., Donard, O.F.X., Pugh, R.S., Moors, A.J., Becker, P.R., 2012. Regional, temporal, and species patterns of mercury in Alaskan seabird eggs: mercury sources and cycling or food web effects? Environ. Pollut. 166, 226232. doi:10.1016/j.envpol.2012.03.004

DeGraaf, R., Tilghman, N., Anderson, S., 1985. Foraging guilds of North American birds. Environ. Manage. 9, 493-536. 
Depew, D.C., Basu, N., Burgess, N.M., Campbell, L.M., Evers, D.C., Grasman, K.A., Scheuhammer, A.M., 2012. Derivation of screening benchmarks for dietary methylmercury exposure for the common loon (Gavia immer): rationale for use in ecological risk assessment. Environ. Toxicol. Chem. 31, 2399-407. doi:10.1002/etc.1971

Driscoll, C., Mason, R., Chan, H., Jacob, D., Pirrone, N., 2013. Mercury as a global pollutant: Sources, pathways, and effects. Environ. Sci. Technol. 47, 4967-4983.

Eagles-Smith, C.A., Ackerman, J.T., 2014. Mercury bioaccumulation in estuarine wetland fishes: evaluating habitats and risk to coastal wildlife. Environ. Pollut. 193, 147-155.

Eagles-Smith, C.A., Ackerman, J.T., Adelsbach, T.L., Takekawa, J.Y., Miles, A.K., Keister, R.A., 2008. Mercury correlations among six tissues for four waterbird species breeding in San Francisco Bay, California, USA. Environ. Toxicol. Chem. 27, 2136-2153. doi:10.1897/08-038.1

Eagles-Smith, C.A., Ackerman, J.T., De La Cruz, S.E.W., Takekawa, J.Y., 2009a. Mercury bioaccumulation and risk to three waterbird foraging guilds is influenced by foraging ecology and breeding stage. Environ. Pollut. 157, 1993-2002. doi:10.1016/j.envpol.2009.03.030

Eagles-Smith, C.A., Ackerman, J.T., Willacker Jr., J.J., Tate, M., Lutz, M., Stewart, A.R., Wiener, J.G., Evers, D.C., Lepak, J., Davis, J., n.d. Spatial and temporal patterns of mercury concentrations in freshwater fishes across western North America. Sci. Total Environ. Submitt.

Eagles-Smith, C.A., Ackerman, J.T., Yee, J., Adelsbach, T.L., 2009b. Mercury demethylation in waterbird livers: dose-response thresholds and differences among species. Environ. Toxicol. Chem. 28, 568-577. doi:10.1897/08-245.1

Eagles-Smith, C.A., Wiener, J.G., Eckley, C., Willacker, J.J., Evers, D.C., Marvin-DiPasquale, M., Obrist, D., Aiken, G., Lepak, J., Jackson, A.K., Webster, J., Stewart, A.R., Davis, J., Fleck, J., Alpers, C., Ackerman, J.T., n.d. Mercury in western North America: a synthesis of environmental contamination, fluxes, bioaccumulation, and risk to fish and wildlife. Sci. Total Environ.

Evers, D., Kaplan, J., Meyer, M., Reaman, P., Braselton, W., Major, A., Burgess, N., Scheuhammer, A.M., 1998. Geographic trend in mercury measured in common loon feathers and blood. Environ. Toxicol. Chem. 17, 173-183.

Evers, D.C., Savoy, L.J., DeSorbo, C.R., Yates, D.E., Hanson, W., Taylor, K.M., Siegel, L.S., Cooley, J.H., Bank, M.S., Major, A., Munney, K., Mower, B.F., Vogel, H.S., Schoch, N., Pokras, M., Goodale, M.W., Fair, J., 2008. Adverse effects from environmental mercury loads on breeding common loons. Ecotoxicology 17, 69-81. doi:10.1007/s10646-007-01687 
Evers, D.C., Schmutz, J.A., Basu, N., DeSorbo, C.R., Fair, J., Gray, C.E., Paruk, J.D., Perkins, M., Regan, K., Uher-koch, B.D., Wright, K.G., 2014. Historic and contemporary mercury exposure and potential risk to yellow-billed loons (Gavia adamsii) breeding in Alaska and Canada. Waterbirds 37, 147-159.

Evers, D.C., Taylor, K.M., Major, A., Taylor, R.J., Poppenga, R.H., Scheuhammer, A.M., 2003. Common loon eggs as indicators of methylmercury availability in North America. Ecotoxicology 12, 69-81.

Evers, D.C., Williams, K.A., Meyer, M.W., Scheuhammer, A.M., Schoch, N., Gilbert, A.T., Siegel, L., Taylor, R.J., Poppenga, R., Perkins, C.R., 2011. Spatial gradients of methylmercury for breeding common loons in the Laurentian Great Lakes region. Ecotoxicology 20, 1609-1625. doi:10.1007/s10646-011-0753-7

Fallacara, D.M., Halbrook, R.S., French, J.B., 2011. Toxic effects of dietary methylmercury on immune function and hematology in American kestrels (Falco sparverius). Environ. Toxicol. Chem. 30, 1320-1327. doi:10.1002/etc.494

Fimreite, N., 1974. Mercury contamination of aquatic birds in northwestern Ontario. J. Wildl. Manage. 38, 120-131. doi:10.2307/3800207

Fimreite, N., 1971. Effects of dietary methylmercury on ring-necked pheasants: with special reference to reproduction, Occasional Paper No. 9. Canadian Wildlife Service, Ottawa.

Fimreite, N., Karstad, L., 1971. Effects of dietary methyl mercury on red-tailed hawks. J. Wildl. Manage. 35, 293-300.

Finkelstein, M.E., Grasman, K.A., Croll, D.A., Tershy, B.R., Keitt, B.S., Jarman, W.M., Smith, D.R., 2007. Contaminant-associated alteration of immune function in black-footed albatross (Phoebastria nigripes), a North Pacific predator. Environ. Toxicol. Chem. 26, 1896-1903. doi:10.1897/06-505R.1

Finley, M.T., Stendell, R.C., 1978. Survival and reproductive success of black ducks fed methyl mercury. Environ. Pollut. 16, 51-64. doi:10.1016/0013-9327(78)90137-4

Finley, M.T., Stickel, W.H., Christensen, R.E., 1979. Mercury residues in tissues of dead and surviving birds fed methylmercury. Bull. Environ. Contam. Toxicol. 21, 105-110. doi:10.1007/BF01685396

Franceschini, M.D., Lane, O.P., Evers, D.C., Reed, J.M., Hoskins, B., Romero, L.M., 2009. The corticosterone stress response and mercury contamination in free-living tree swallows, Tachycineta bicolor. Ecotoxicology 18, 514-521. doi:10.1007/s10646-009-0309-2 
Frederick, P., Jayasena, N., 2010. Altered pairing behaviour and reproductive success in white ibises exposed to environmentally relevant concentrations of methylmercury. Proc. R. Soc. B Biol. Sci. 278, 1851-1857. doi:10.1098/rspb.2010.2189

Furness, R.W.W., Muirhead, S.J.J., Woodburn, M., 1986. Using bird feathers to measure mercury in the environment: relationships between mercury content and moult. Mar. Pollut. Bull. 17, 27-30. doi:Doi 10.1016/0025-326x(86)90801-5

Gibson, L.A., Lavoie, R.A., Bissegger, S., Campbell, L.M., Langlois, V.S., 2014. A positive correlation between mercury and oxidative stress-related gene expression (GPX3 and GSTM3) is measured in female double-crested cormorant blood. Ecotoxicology 23, 1004 14. doi:10.1007/s10646-014-1243-5

Goutte, A., Bustamante, P., Barbraud, C., Delord, K., Weimerskirch, H., Chastel, O., 2014. Demographic responses to mercury exposure in two closely related Antarctic top predators. Ecology 95, 1075-1086.

Hallinger, K.K., Cristol, D.A., 2011. The role of weather in mediating the effect of mercury exposure on reproductive success in tree swallows. Ecotoxicology 20, 1368-1377. doi:10.1007/s10646-011-0694-1

Hawley, D.M., Hallinger, K.K., Cristol, D.A., 2009. Compromised immune competence in freeliving tree swallows exposed to mercury. Ecotoxicology 18, 499-503. doi:10.1007/s10646009-0307-4

Heinz, G.H., 1979. Methylmercury: Reproductive and behavioral effects on three generations of mallard ducks. J. Wildl. Manage. 43, 394-401.

Heinz, G.H., Hoffman, D.J., Klimstra, J.D., Stebbins, K.R., 2010. Predicting mercury concentrations in mallard eggs from mercury in the diet or blood of adult females and from duckling down feathers. Environ. Toxicol. Chem. 29, 389-392. doi:10.1002/etc.50

Heinz, G.H., Hoffman, D.J., Klimstra, J.D., Stebbins, K.R., 2009a. Rapid increases in mercury concentrations in the eggs of mallards fed methylmercury. Environ. Toxicol. Chem. 28, 1979-1981. doi:10.1897/09-060.1

Heinz, G.H., Hoffman, D.J., Klimstra, J.D., Stebbins, K.R., Kondrad, S.L., Erwin, C.A., 2009b. Species differences in the sensitivity of avian embryos to methylmercury. Arch. Environ. Contam. Toxicol. 56, 129-138. doi:10.1007/s00244-008-9160-3

Henny, C.J., Blus, L.J., Grove, R.A., 1990. Western grebe, Aechmorphorus occidentalis, wintering biology and contaminant accumulation in Commencement Bay, Puget Sound, Washington. Can. Field-Naturalist 104, 460-472. 
Henny, C.J., Blus, L.J., Grove, R.A., Thompson, S.P., 1991. Accumulation of trace elements and organochlorines by surf scoters wintering in the Pacific Northwest. Northwest. Nat. 72, 4360 .

Henny, C.J., Hill, E.F., Grove, R.A., Kaiser, J.L., 2007. Mercury and drought along the lower Carson River, Nevada: I. Snowy egret and black-crowned night-heron annual exposure to mercury, 1997-2006. Arch. Environ. Contam. Toxicol. 53, 269-280. doi:10.1007/s00244006-0163-7

Henny, C.J., Hill, E.F., Hoffman, D.J., Spalding, M.G., Grove, R.A., 2002. Nineteenth century mercury: hazard to wading birds and cormorants of the Carson River, Nevada. Ecotoxicology 11, 213-231.

Herring, G., Ackerman, J.T., Eagles-Smith, C.A., 2010. Embryo malposition as a potential mechanism for mercury-induced hatching failure in bird eggs. Environ. Toxicol. Chem. 29, 1788-1794. doi:10.1002/etc.208

Hoffman, D.J., Eagles-Smith, C.A., Ackerman, J.T., Adelsbach, T.L., Stebbins, K.R., 2011. Oxidative stress response of Forster's terns (Sterna forsteri) and Caspian terns (Hydroprogne caspia) to mercury and selenium bioaccumulation in liver, kidney, and brain. Environ. Toxicol. Chem. 30, 920-929. doi:10.1002/etc.459

Hoffman, D.J., Heinz, G.H., 1998. Effects of mercury and selenium on glutathione metabolism and oxidative stress in mallard ducks. Environ. Toxicol. Chem. 17, 161-166.

Hoffman, D.J., Ohlendorf, H.M., Marn, C.M., Pendleton, G.W., 1998. Association of mercury and selenium with altered glutathione metabolism and oxidative stress in diving ducks from the San Francisco Bay region, USA. Environ. Toxicol. Chem. 17, 167-172.

Jackson, A.K., Evers, D.C., Adams, E.M., Cristol, D.A., Eagles-Smith, C.A., Edmonds, S.T., Gray, C.E., Hoskins, B., Lane, O.P., Sauer, A., Tear, T., 2015. Songbirds as sentinels of mercury in terrestrial habitats of eastern North America. Ecotoxicology 24, 453-467. doi:10.1007/s10646-014-1394-4

Jackson, A.K., Evers, D.C., Etterson, M.A., Condon, A.M., Folsom, S.B., Detweiler, J., Schmerfeld, J., Cristol, D.A., 2011a. Mercury exposure affects the reproductive success of a free-living terrestrial songbird, the Carolina wren (Thryothorus ludovicianus). Auk 128, 759-769.

Jackson, A.K., Evers, D.C., Folsom, S.B., Condon, A.M., Diener, J., Goodrick, L.F., McGann, A.J., Schmerfeld, J., Cristol, D.A., 2011b. Mercury exposure in terrestrial birds far downstream of an historical point source. Environ. Pollut. 159, 3302-3308. doi:10.1016/j.envpol.2011.08.046 
Kennamer, R.A., Stout, J.R., Jackson, B.P., Colwell, S. V., Brisbin, I.L., Burger, J., 2005. Mercury patterns in wood duck eggs from a contaminated reservoir in South Carolina, USA. Environ. Toxicol. Chem. 24, 1793-1800. doi:Doi 10.1897/03-661.1

Kenow, K.P., Meyer, M.W., Hines, R.K., Karasov, W.H., 2007. Distribution and accumulation of mercury in tissues of captive-reared common loon (Gavia immer) chicks. Environ. Toxicol. Chem. 26, 1047-1055.

Kenow, K.P., Meyer, M.W., Rossmann, R., Gendron-Fitzpatrick, A., Gray, B.R., 2011. Effects of injected methylmercury on the hatching of common loon (Gavia immer) eggs. Ecotoxicology 20, 1684-93. doi:10.1007/s10646-011-0743-9

Kenow, K.P., Meyer, M.W., Rossmann, R., Gray, B.R., Arts, M.T., 2015. Influence of in ovo mercury exposure, lake acidity, and other factors on common loon egg and chick quality in Wisconsin. Environ. Toxicol. Chem. 34, 1870-1880. doi:10.1002/etc.3001

Kobiela, M.E., Cristol, D.A., Swaddle, J.P., 2015. Risk-taking behaviours in zebra finches affected by mercury exposure. Anim. Behav. 103, 153-160. doi:10.1016/j.anbehav.2015.02.024

Mallory, M.L., Braune, B.M., 2012. Tracking contaminants in seabirds of Arctic Canada: temporal and spatial insights. Mar. Pollut. Bull. 64, 1475-84. doi:10.1016/j.marpolbul.2012.05.012

Mason, R.P., Abbott, M.L., Bodaly, R.A., Bullock, O.R., Driscoll, C.T., Evers, D., Lindberg, S.E., Murray, M., Swain, E.B., 2005. Monitoring the response to changing mercury deposition. Environ. Sci. Technol. 39, 14A-22A. doi:10.1021/es0531551

Monteiro, L., Furness, R., 1997. Accelerated increase in mercury contamination in North Atlantic mesopelagic food chains as indicated by time series of seabird feathers. Environ. Toxicol. Chem. 16, 2489-2493.

Monteiro, L.R., Furness, R.W., 1995. Seabirds as monitors of mercury in the marine environment. Water. Air. Soil Pollut. 80, 851-870.

Moore, C.S., Cristol, D.A., Maddux, S.L., Varian-Ramos, C.W., Bradley, E.L., 2014. Lifelong exposure to methylmercury disrupts stress-induced corticosterone response in zebra finches (Taeniopygia guttata). Environ. Toxicol. Chem. 33, 1072-6. doi:10.1002/etc.2521

Murkin, H.R., Murkin, E.J., Ball, J.P., 1997. Avian habitat selection and prairie wetland dynamics: a 10-year experiment. Ecol. Appl. 7, 1144-1159. doi:10.1890/10510761(1997)007[1144:AHSAPW]2.0.CO;2 
National Assessment Synthesis Team, 2001. Climate change impacts of the United States: the potential consequences of climate variability and change. Cambridge University Press, Cambridge, UK.

Newton, I., Haas, M.B., 1988. Pollutants in merlin eggs and their effects on breeding. Breed. Birds 81, 258-269.

Niemuth, N.D., Estey, M.E., Reynolds, R.E., Loesch, C.R., Meeks, W.A., 2006. Use of wetlands by spring-migrant shorebirds in agricultural landscapes of North Dakota's Drift Prairie. Wetlands 26, 30-39. doi:10.1672/0277-5212(2006)26[30:UOWBSS]2.0.CO;2

Ohlendorf, H.M., Marois, K.C., Lowe, R.W., Harvey, T.E., Kelly, P.R., 1987. Environmental contaminants and diving ducks in San Francisco Bay, in: Alice Q. Howard (Ed.), Selenium and Agricultural Drainage: Implications for San Francisco Bay and the California Environment. The Bay Institue of San Francisco and Department of Conservation and Resource Studies, Univeristy of California at Berkeley, Berkeley, California, pp. 60-69.

Ou, L., Varian-Ramos, C.W., Cristol, D.A., 2015. Effect of laying sequence on egg mercury in captive zebra finches: an interpretation considering individual variation. Environ. Toxicol. Chem. 34, 1787-1792. doi:10.1002/etc.2976

Post, D.M., 2002. The long and short of food-chain length. Trends Ecol. Evol. 17, 269-277.

Provencher, J.F., Mallory, M.L., Braune, B.M., Forbes, M.R., Gilchrist, H.G., 2014. Mercury and marine birds in Arctic Canada: effects, current trends, and why we should be paying closer attention. Environ. Rev. 22, 244-255. doi:10.1139/er-2013-0072

Ricca, M.A., Miles, A.K., Anthony, R.G., 2008. Sources of organochlorine contaminants and mercury in seabirds from the Aleutian archipelago of Alaska: inferences from spatial and trophic variation. Sci. Total Environ. 406, 308-323. doi:10.1016/j.scitotenv.2008.06.030

Rigét, F., Braune, B., Bignert, A., Wilson, S., Aars, J., Born, E., Dam, M., Dietz, R., Evans, M., Evans, T., Gamberg, M., Gantner, N., Green, N., Gunnlaugsdóttir, H., Kannan, K., Letcher, R., Muir, D., Roach, P., Sonne, C., Stern, G., Wiig, O., 2011. Temporal trends of Hg in Arctic biota, an update. Sci. Total Environ. 409, 3520-6.

doi:10.1016/j.scitotenv.2011.05.002

Rimmer, C.C., McFarland, K.P., Evers, D.C., Miller, E.K., Aubry, Y., Busby, D., Taylor, R.J., 2005. Mercury concentrations in Bicknell's thrush and other insectivorous passerines in montane forests of northeastern North America. Ecotoxicology 14, 223-240.

Scheuhammer, A., Wong, A.H.K., Bond, D., 1998. Mercury and selenium accumulation in common loons (Gavia immer) and common mergansers (Mergus merganser) from eastern Canada. Environ. Toxicol. Chem. 17, 197-201. 
Scheuhammer, A.M., 1988. Chronic dietary toxicity of methylmercury in the zebra finch, Poephila guttata. Bull. Environ. Contam. Toxicol. 40, 123-30. doi:10.1007/BF01689398

Scheuhammer, A.M., Basu, N., Burgess, N.M., Elliott, J.E., Campbell, G.D., Wayland, M., Champoux, L., Rodrigue, J., 2008. Relationships among mercury, selenium, and neurochemical parameters in common loons (Gavia immer) and bald eagles (Haliaeetus leucocephalus). Ecotoxicology 17, 93-101. doi:10.1007/s10646-007-0170-0

Scheuhammer, A.M., Meyer, M.W., Sandheinrich, M.B., Murray, M.W., 2007. Effects of environmental methylmercury on the health of wild birds, mammals, and fish. Ambio 36, $12-18$.

Seber, G.A.F., 1982. The estimation of animal abundance and related parameters, Second edition. Macmillan, New York.

Shore, R.F., Pereira, E., Walker, L.A., Thompson, D.R., 2011. Mercury in nonmarine birds and mammals, in: Beyer, W.N., Meador, J.P. (Eds.), Environmental Contaminants in Biota: Interpreting Tissue Concentrations, Second Edition. CRC Press, Boca Raton, pp. 609-626.

Singer, M.B., Aalto, R., James, L.A., Kilham, N.E., Higson, J.L., Ghoshal, S., 2013. Enduring legacy of a toxic fan via episodic redistribution of California gold mining debris. Proc. Natl. Acad. Sci. 110, 18436-18441. doi:10.1073/pnas.1302295110

Skagen, S.K., Granfors, D.A., Melcher, C.P., 2008. On determining the significance of ephemeral continental wetlands to North American migratory shorebirds. Auk 125, 20-29. doi:10.1525/auk.2008.125.1.20

Spann, J.W., Heath, R.G., Kreitzer, J.F., Locke, L.N., 1972. Ethyl mercury p-toluene sulfonanilide: lethal and reproductive effects on pheasants. Science 175, 328-331.

Stebbins, K.R., Klimstra, J.D., Eagles-Smith, C.A., Ackerman, J.T., Heinz, G.H., 2009. A nonlethal microsampling technique to monitor the effects of mercury on wild bird eggs. Environ. Toxicol. Chem. 28, 465-470. doi:10.1897/08-316.1

Stickel, L., Wiemeyer, S., Blus, L.J., 1973. Pesticide residues in eggs of wild birds: Adjustment for loss of moisture and lipid. Bull. Environ. Contam. Toxicol. 9, 193-196.

Sunderland, E.M., Krabbenhoft, D.P., Moreau, J.W., Strode, S.A., Landing, W.M., 2009. Mercury sources, distribution, and bioavailability in the North Pacific Ocean: insights from data and models. Global Biogeochem. Cycles 23, n/a-n/a. doi:10.1029/2008GB003425

Tartu, S., Angelier, F., Wingfield, J.C., Bustamante, P., Labadie, P., Budzinski, H., Weimerskirch, H., Bustnes, J.O., Chastel, O., 2015. Corticosterone, prolactin and egg neglect behavior in relation to mercury and legacy POPs in a long-lived Antarctic bird. Sci. Total Environ. 505, 180-188. doi:10.1016/j.scitotenv.2014.10.008 
Tartu, S., Bustamante, P., Angelier, F., Lendvai, Á.Z., Moe, B., Blévin, P., Bech, C., Gabrielsen, G.W., Bustnes, J.O., Chastel, O., 2015. Mercury exposure, stress and prolactin secretion in an Arctic seabird: an experimental study. Funct. Ecol. n/a-n/a. doi:10.1111/1365-

2435.12534

Tartu, S., Goutte, A., Bustamante, P., Angelier, F., Moe, B., Clément-Chastel, C., Bech, C., Gabrielsen, G.W., Bustnes, J.O., Chastel, O., 2013. To breed or not to breed: endocrine response to mercury contamination by an Arctic seabird. Biol. Lett. 9, 1-4.

doi:10.1098/rsbl.2013.0317

Thompson, D., Furness, R., 1989. Comparison of the levels of total and organic mercury in seabird feathers. Mar. Pollut. Bull. 20, 577-579.

Thompson, D.R., 1996. Mercury in birds and terrestrial mammals, in: Beyer, W.N., Heinz, G.H., Redmon-Norwood, A.W. (Eds.), Environmental Contaminants in Wildlife, Interpreting Tissue Concentrations. CRC Press LCC, Boca Raton, Florida, pp. 341-356.

Thompson, D.R., Bearhop, S., Speakman, J.R., Furness, R.W., 1998. Feathers as a means of monitoring mercury in seabirds: Insights from stable isotope analysis. Environ. Pollut. 101, 193-200.

Thompson, D.R., Furness, R.W., 1989. The chemical form of mercury stored in South Atlantic seabirds. Environ. Pollut. 60, 305-17.

Tiner, R.W.J., 1984. Wetlands of the United States: current status and recent trends. U.S. Department of the Interior, Fish and Wildlife Service.

Ullrich, S.M., Tanton, T.W., Abdrashitova, S.A., 2001. Mercury in the aquatic environment: a review of factors affecting methylation. Crit. Rev. Environ. Sci. Technol. 31, 241-293. doi:10.1080/20016491089226

Varian-Ramos, C.W., Swaddle, J.P., Cristol, D.A., 2014. Mercury reduces avian reproductive success and imposes selection: an experimental study with adult- or lifetime-exposure in zebra finch. PLoS One 9, e95674. doi:10.1371/journal.pone.0095674

Weiss-Penzias, P.S., Gay, D.A., Brigham, M.E., Parsons, M.T., Gustin, M.S., ter Schure, A., n.d. Trends in mercury wet deposition and mercury air concentrations across the U.S. and Canada. Sci. Total Environ. in press.

Weseloh, D.V.C., Moore, D.J., Hebert, C.E., De Solla, S.R., Braune, B.M., McGoldrick, D.J., 2011. Current concentrations and spatial and temporal trends in mercury in Great Lakes Herring Gull eggs, 1974-2009. Ecotoxicology 20, 1644-1658. doi:10.1007/s10646-011$0755-5$ 
Wiener, J.G., Krabbenhoft, D.P., Heinz, G.H., Scheuhammer, A.M., 2003. Ecotoxicology of mercury, in: Hoffman, D.J., Rattner, B.A., Burton, G.A.J., Cairns, J.J. (Eds.), Handbook of Ecotoxicology, Second Edition. CRC Press LCC, Boca Raton, Florida, pp. 409-463.

Zillioux, E.., Porcella, D.B., Benoit, J.M., 1993. Mercury cycling and effects in freshwater wetland ecosystems. Environ. Toxicol. Chem. 12, 2245-2264. doi:10.1897/15528618(1993)12[2245:MCAEIF]2.0.CO;2 


\section{TABLES}

Table 1. Summary of toxicity benchmarks for the effects of methylmercury exposure on birds. Toxicity benchmarks were translated from the original tissue from which they were derived into blood-equivalent units using correlational models of total mercury concentrations between blood and various tissues. The table is sorted from the lowest to the highest blood-equivalent total mercury concentration where a toxic effect of methylmercury on birds was observed. Effects on juvenile birds were excluded due to the temporal complexity of methylmercury concentrations in chicks as they age, and the inability to reliably translate chick total mercury concentrations into equivalent total mercury concentrations in adult blood. Acronyms are blood $=$ whole blood; RBCs $=$ red blood cells; $\mathrm{ww}=$ wet weight; $\mathrm{dw}=$ dry weight; fww = fresh wet weight; $\mathrm{THg}=$ total mercury concentration; $\mathrm{MeHg}=$ methylmercury concentration; $\mathrm{LC}_{50}$ : lethal concentration where $50 \%$ mortality occurs; na $=$ no equation was needed to translate into blood total mercury concentration.

\begin{tabular}{|c|c|c|c|c|c|c|c|c|}
\hline \multirow[b]{2}{*}{$\begin{array}{c}\text { Impairment } \\
\text { category }\end{array}$} & \multirow[b]{2}{*}{$\mathrm{Hg}$ toxicity effect } & \multirow{2}{*}{$\begin{array}{c}\text { Blood- } \\
\text { equivalent } \\
\text { THg } \\
(\mu \mathrm{g} / \mathrm{g} \mathrm{ww}) \\
\end{array}$} & \multicolumn{3}{|c|}{ Original tissue $\mathrm{THg}$} & \multirow[b]{2}{*}{ Bird species } & \multirow[b]{2}{*}{ Study $^{\mathrm{a}}$} & \multirow[b]{2}{*}{$\begin{array}{l}\text { Blood- } \\
\text { equivalent } \\
\text { equation }\end{array}$} \\
\hline & & & Tissue & Benchmark & Units & & & \\
\hline $\begin{array}{l}\text { Health and } \\
\text { physiology }\end{array}$ & $\begin{array}{l}\text { Oxidative stress response: } \\
\text { negative relationship with } \\
\text { thiobarbituric acid activity (below } \\
\text { this concentration) }^{\mathrm{d}}\end{array}$ & 0.2 & Liver & 1.60 & $\mu \mathrm{g} / \mathrm{g} \mathrm{dw}$ & Lesser Scaup & Custer et al. (2000) & 1 \\
\hline $\begin{array}{l}\text { Health and } \\
\text { physiology }\end{array}$ & $\begin{array}{l}\text { Altered gene expression in } \\
\text { females (below this } \\
\text { concentration) }^{\mathrm{d}}\end{array}$ & 0.3 & RBCs & 1.20 & $\mu \mathrm{g} / \mathrm{g} \mathrm{dw}$ & $\begin{array}{l}\text { Double-crested } \\
\text { Cormorant }\end{array}$ & $\begin{array}{l}\text { Gibson et al. } \\
\quad(2014)\end{array}$ & 2 \\
\hline Reproduction & $\begin{array}{l}\text { Median for males that raised only } \\
1 \text { of } 2 \text { chicks; no males above this } \\
\text { threshold successfully raised } 2 \\
\text { chicks }\end{array}$ & 0.3 & RBCs & 1.20 & $\mu \mathrm{g} / \mathrm{g} \mathrm{dw}$ & $\begin{array}{l}\text { Black-legged } \\
\text { Kittiwake }\end{array}$ & Tartu et al. (2015b) & 2 \\
\hline Reproduction & $\begin{array}{l}\text { Decreased egg hatchability (mean } \\
\text { of eggs from dosed females) }\end{array}$ & 0.3 & Egg & 0.15 & $\mu \mathrm{g} / \mathrm{g} w \mathrm{w}$ & $\begin{array}{l}\text { Ring-necked } \\
\text { Pheasant }\end{array}$ & Spann et al. (1972) ${ }^{\mathrm{a}}$ & 3 \\
\hline Reproduction & $\begin{array}{l}\text { Median for birds that skipped } \\
\text { breeding (higher than birds that } \\
\text { bred); altered hormones }\end{array}$ & 0.4 & RBCs & 2.00 & $\mu \mathrm{g} / \mathrm{g} \mathrm{dw}$ & $\begin{array}{l}\text { Black-legged } \\
\text { Kittiwake }\end{array}$ & Tartu et al. (2013) & 2 \\
\hline Behavioral & $\begin{array}{l}\text { Increased egg neglect for males } \\
\text { (lower concentrations had no } \\
\text { observed egg neglect) }\end{array}$ & 0.4 & RBCs & 2.00 & $\mu \mathrm{g} / \mathrm{g} \mathrm{dw}$ & Snow Petrel & Tartu et al. (2015a) & 2 \\
\hline
\end{tabular}




\begin{tabular}{|c|c|c|c|c|c|c|c|c|}
\hline Reproduction & $\begin{array}{l}\text { Egg hatchability: } \mathrm{LC}_{50} \text { of egg- } \\
\text { injected birds ranked as high } \\
\text { sensitivity to } \mathrm{MeHg}\end{array}$ & 0.5 & Egg & 0.25 & $\mu \mathrm{g} / \mathrm{g} w \mathrm{w}$ & Multiple & $\begin{array}{l}\text { Heinz et al. } \\
\qquad(2009 a)^{a}\end{array}$ & 3 \\
\hline Reproduction & $\begin{array}{l}10 \% \text { reduction in probability of } \\
\text { nest success }\end{array}$ & 0.7 & Blood & 0.70 & $\mu \mathrm{g} / \mathrm{g} \mathrm{ww}$ & Carolina Wren & $\begin{array}{l}\text { Jackson et al. } \\
\qquad(2011)\end{array}$ & na \\
\hline Reproduction & $\begin{array}{l}13 \% \text { decrease in productive nests; } \\
\text { altered courtship behaviors (mean } \\
\text { of dosed birds) }\end{array}$ & 0.7 & Blood & 0.73 & $\mu \mathrm{g} / \mathrm{g} \mathrm{ww}$ & White Ibis & 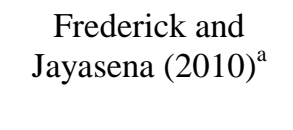 & na \\
\hline Reproduction & $\begin{array}{l}\text { Probability of breeding } \\
\text { successfully the subsequent year } \\
\text { drops below } 50 \%\end{array}$ & 0.8 & $\mathrm{RBCs}$ & 3.90 & $\mu \mathrm{g} / \mathrm{g} \mathrm{dw}$ & South Polar Skua & Goutte et al. (2014) & 2 \\
\hline Reproduction & $\begin{array}{l}\text { Proposed indicative concentration } \\
\text { for impaired reproduction (review) }\end{array}$ & 0.8 & Liver & 2.00 & $\mu \mathrm{g} / \mathrm{g} w \mathrm{w}$ & Multiple & Shore et al. (2011) & 1 \\
\hline Reproduction & $\begin{array}{l}10 \% \text { reduction in max. } \\
\text { productivity }\end{array}$ & 0.9 & Blood & 0.90 & $\mu \mathrm{g} / \mathrm{g} \mathrm{ww}$ & Common Loon & $\begin{array}{l}\text { Burgess and Meyer } \\
\text { (2008) }\end{array}$ & na \\
\hline $\begin{array}{l}\text { Health and } \\
\text { physiology }\end{array}$ & $\begin{array}{l}\text { Negative relationship with cortisol } \\
\text { (below this concentration) }{ }^{\mathrm{d}}\end{array}$ & 1.0 & Blood & 1.00 & $\mu \mathrm{g} / \mathrm{g} \mathrm{ww}$ & Tree Swallow & $\begin{array}{l}\text { Franceschini et al. } \\
\qquad(2009)\end{array}$ & na \\
\hline Reproduction & Decreased egg hatchability & 1.1 & Egg & 0.50 & $\mu \mathrm{g} / \mathrm{g} w \mathrm{w}$ & $\begin{array}{l}\text { Ring-necked } \\
\text { Pheasant }\end{array}$ & Fimreite (1971) & 3 \\
\hline $\begin{array}{l}\text { Health and } \\
\text { physiology }\end{array}$ & $\begin{array}{l}\text { MeHg demethylation threshold in } \\
\text { liver }\end{array}$ & 1.2 & Liver & 8.51 & $\mu \mathrm{g} / \mathrm{g} \mathrm{dw}$ & $\begin{array}{l}\text { Forster's Tern, } \\
\text { Caspian Tern, } \\
\text { American Avocet, } \\
\text { Black-necked Stilt }\end{array}$ & $\begin{array}{l}\text { Eagles-Smith et al. } \\
\qquad(2009 b)\end{array}$ & 1 \\
\hline Reproduction & $\begin{array}{l}20 \% \text { reduction in probability of } \\
\text { nest success }\end{array}$ & 1.2 & Blood & 1.20 & $\mu \mathrm{g} / \mathrm{g} \mathrm{ww}$ & Carolina Wren & $\begin{array}{l}\text { Jackson et al. } \\
\qquad(2011)\end{array}$ & na \\
\hline Reproduction & $\begin{array}{l}\text { Egg hatchability: } \mathrm{LC}_{50} \text { of egg- } \\
\text { injected and maternally derived } \\
\mathrm{MeHg}\end{array}$ & 1.2 & Egg & 0.56 & $\mu \mathrm{g} / \mathrm{g} w \mathrm{w}$ & $\begin{array}{l}\text { Thick-billed } \\
\text { Murre }\end{array}$ & $\begin{array}{l}\text { Braune et al. } \\
\qquad(2012)^{\mathrm{a}}\end{array}$ & 3 \\
\hline $\begin{array}{l}\text { Health and } \\
\text { physiology }\end{array}$ & $\begin{array}{l}\text { Glutathione metabolism and } \\
\text { antioxidant activity (effect on } \\
\text { associated enzymes below this } \\
\text { concentration) }^{\mathrm{d}}\end{array}$ & 1.2 & Liver & 9.00 & $\mu \mathrm{g} / \mathrm{g} \mathrm{dw}$ & Ruddy Duck & $\begin{array}{l}\text { Hoffman et al. } \\
\text { (1998) }\end{array}$ & 1 \\
\hline Reproduction & Decrease in productivity & 1.3 & Egg & 3.00 & $\mu \mathrm{g} / \mathrm{g} \mathrm{dw}$ & Merlin & $\begin{array}{l}\text { Newton and Haas } \\
\text { (1988) }\end{array}$ & 3 \\
\hline
\end{tabular}




\begin{tabular}{|c|c|c|c|c|c|c|c|}
\hline Reproduction & $\begin{array}{l}\text { Proposed indicative concentration } \\
\text { for impaired reproduction (review) }\end{array}$ & 1.3 & Egg & 0.60 & $\mu \mathrm{g} / \mathrm{g} w \mathrm{w}$ & Multiple & Shore et al. (2011) \\
\hline Behavioral & Impaired behavior (review) & 1.4 & $\begin{array}{c}\text { Diet } \\
\text { (fish) }\end{array}$ & 0.10 & $\mu \mathrm{g} / \mathrm{g} w \mathrm{w}$ & Common Loon & $\begin{array}{l}\text { Depew et al. } \\
\qquad(2012)\end{array}$ \\
\hline $\begin{array}{l}\text { Health and } \\
\text { physiology }\end{array}$ & $\begin{array}{l}\text { Negative relationship with body } \\
\text { condition (below this } \\
\text { concentration) }\end{array}$ & 1.6 & Blood & 1.56 & $\mu \mathrm{g} / \mathrm{g} w \mathrm{w}$ & Clapper Rail & $\begin{array}{l}\text { Ackerman et al. } \\
\qquad(2012)\end{array}$ \\
\hline Reproduction & $\begin{array}{l}\text { Decreased egg hatchability (mean } \\
\text { of contaminated site) }\end{array}$ & 1.6 & Egg & 2.86 & $\mu \mathrm{g} / \mathrm{g} \mathrm{dw}$ & House Wren & Custer et al. (2007) \\
\hline Reproduction & $\begin{array}{l}15 \% \text { decrease in productive nests; } \\
\text { altered courtship behaviors (mean } \\
\text { of dosed birds) }\end{array}$ & 1.6 & Blood & 1.60 & $\mu \mathrm{g} / \mathrm{g}$ ww & White Ibis & $\begin{array}{c}\text { Frederick and } \\
\text { Jayasena }(2010)^{\mathrm{a}}\end{array}$ \\
\hline Reproduction & $\begin{array}{l}30 \% \text { reduction in probability of } \\
\text { nest success }\end{array}$ & 1.7 & Blood & 1.70 & $\mu \mathrm{g} / \mathrm{g} \mathrm{ww}$ & Carolina Wren & $\begin{array}{l}\text { Jackson et al. } \\
\qquad(2011)\end{array}$ \\
\hline Reproduction & Impaired reproduction & 1.8 & Egg & 0.80 & $\mu \mathrm{g} / \mathrm{g} w \mathrm{w}$ & Mallard & Heinz $(1979)^{\mathrm{a}}$ \\
\hline Reproduction & $\begin{array}{l}23 \% \text { reduction in max. } \\
\text { productivity }\end{array}$ & 2.0 & Blood & 2.00 & $\mu \mathrm{g} / \mathrm{g} \mathrm{ww}$ & Common Loon & $\begin{array}{l}\text { Burgess and Meyer } \\
\text { (2008) }\end{array}$ \\
\hline $\begin{array}{l}\text { Health and } \\
\text { physiology }\end{array}$ & $\begin{array}{l}\text { Proposed concentration for } \\
\text { adverse effects in waterbirds } \\
\text { (review) }\end{array}$ & 2.0 & Liver & 5.00 & $\mu \mathrm{g} / \mathrm{g} w \mathrm{w}$ & Multiple & $\begin{array}{l}\text { Zillioux et al. } \\
\qquad(1993)\end{array}$ \\
\hline Reproduction & Impaired productivity (review) & 2.1 & $\begin{array}{l}\text { Diet } \\
\text { (fish) }\end{array}$ & 0.18 & $\mu \mathrm{g} / \mathrm{g} \mathrm{ww}$ & Common Loon & $\begin{array}{l}\text { Depew et al. } \\
\quad(2012)\end{array}$ \\
\hline Reproduction & $\begin{array}{l}\text { Probability of successfully raising } \\
2 \text { chicks the subsequent year drops } \\
\text { below } 50 \%\end{array}$ & 2.1 & RBCs & 10.00 & $\mu \mathrm{g} / \mathrm{g} \mathrm{dw}$ & Brown Skua & Goutte et al. (2014) \\
\hline Reproduction & $\begin{array}{l}40 \% \text { reduction in probability of } \\
\text { nest success }\end{array}$ & 2.1 & Blood & 2.10 & $\mu \mathrm{g} / \mathrm{g} w \mathrm{w}$ & Carolina Wren & $\begin{array}{l}\text { Jackson et al. } \\
\qquad(2011)\end{array}$ \\
\hline Reproduction & $\begin{array}{l}\text { General impaired hatchability and } \\
\text { embryonic mortality (review) }\end{array}$ & 2.3 & Egg & 1.00 & $\mu \mathrm{g} / \mathrm{g}$ fww & Multiple & $\begin{array}{l}\text { Scheuhammer et al. } \\
\qquad(2007)\end{array}$ \\
\hline Reproduction & $\begin{array}{l}\text { Egg hatchability: } \mathrm{LC}_{50} \text { of egg- } \\
\text { injected birds ranked as moderate } \\
\text { sensitivity to } \mathrm{MeHg}\end{array}$ & 2.3 & Egg & 1.00 & $\mu \mathrm{g} / \mathrm{g} w \mathrm{w}$ & Multiple & $\begin{array}{l}\text { Heinz et al. } \\
\qquad(2009 a)^{a}\end{array}$ \\
\hline Reproduction & $\begin{array}{l}50 \% \text { reduction in probability of } \\
\text { nest success }\end{array}$ & 2.5 & Blood & 2.50 & $\mu \mathrm{g} / \mathrm{g} \mathrm{ww}$ & Carolina Wren & $\begin{array}{l}\text { Jackson et al. } \\
\quad(2011)\end{array}$ \\
\hline
\end{tabular}




\begin{tabular}{|c|c|c|c|c|c|c|c|}
\hline Reproduction & $\begin{array}{l}\text { Egg hatchability: } \mathrm{LC}_{50} \text { of egg- } \\
\text { injected and maternally derived } \\
\mathrm{MeHg}\end{array}$ & 2.5 & Egg & 1.10 & $\mu \mathrm{g} / \mathrm{g} \mathrm{ww}$ & Arctic Tern & $\begin{array}{l}\text { Braune et al. } \\
\qquad(2012)^{\mathrm{a}}\end{array}$ \\
\hline Reproduction & $\begin{array}{l}10 \% \text { probability of embryo being } \\
\text { malpositioned in egg }\end{array}$ & 2.7 & Egg & 1.20 & $\mu \mathrm{g} / \mathrm{g}$ fww & Forster's Tern & $\begin{array}{l}\text { Herring et al. } \\
\qquad(2010)\end{array}$ \\
\hline Reproduction & Impaired productivity & 2.8 & $\begin{array}{l}\text { Diet } \\
\text { (fish) }\end{array}$ & 0.30 & $\mu \mathrm{g} / \mathrm{g} \mathrm{ww}$ & Common Loon & Barr (1986) \\
\hline $\begin{array}{l}\text { Health and } \\
\text { physiology }\end{array}$ & $\begin{array}{l}\text { Decreased immunocompetence } \\
\text { (mean of contaminated site) }\end{array}$ & 2.9 & Blood & 2.85 & $\mu \mathrm{g} / \mathrm{g} \mathrm{ww}$ & Tree Swallow & $\begin{array}{l}\text { Hawley et al. } \\
\qquad(2009)\end{array}$ \\
\hline Reproduction & $\begin{array}{l}35 \% \text { reduction in max. } \\
\text { productivity }\end{array}$ & 3.0 & Blood & 3.00 & $\mu \mathrm{g} / \mathrm{g} \mathrm{ww}$ & Common Loon & $\begin{array}{l}\text { Burgess and Meyer } \\
\qquad(2008)\end{array}$ \\
\hline Reproduction & Reproductive failure & 3.0 & Blood & 3.00 & $\mu \mathrm{g} / \mathrm{g} w \mathrm{w}$ & Common Loon & Evers et al. (2008) \\
\hline Reproduction & $\begin{array}{l}\text { Decreased hatching and fledging } \\
\text { success when ambient temps. } \\
\text { increased (mean of contaminated } \\
\text { site) }\end{array}$ & 3.0 & Blood & 3.03 & $\mu \mathrm{g} / \mathrm{g} \mathrm{ww}$ & Tree Swallow & $\begin{array}{l}\text { Hallinger and } \\
\text { Cristol (2011) }\end{array}$ \\
\hline $\begin{array}{l}\text { Health and } \\
\text { physiology }\end{array}$ & $\begin{array}{l}\text { Suggested threshold above which } \\
\text { demethylation occurs in a dose } \\
\text { dependent relationship }\end{array}$ & 3.2 & Liver & 8.00 & $\mu \mathrm{g} / \mathrm{g} \mathrm{ww}$ & $\begin{array}{l}\text { Black-crowned } \\
\text { Night-heron, } \\
\text { Snowy Egret, } \\
\text { Double-crested } \\
\text { Cormorant }\end{array}$ & Henny et al. (2002) \\
\hline Reproduction & $\begin{array}{l}20 \% \text { probability of embryo being } \\
\text { malpositioned in egg }\end{array}$ & 3.2 & Egg & 1.40 & $\mu \mathrm{g} / \mathrm{g}$ fww & Forster's Tern & $\begin{array}{l}\text { Herring et al. } \\
\qquad(2010)\end{array}$ \\
\hline Reproduction & Failed productivity (review) & 3.4 & $\begin{array}{l}\text { Diet } \\
\text { (fish) }\end{array}$ & 0.40 & $\mu \mathrm{g} / \mathrm{g} w \mathrm{w}$ & Common Loon & $\begin{array}{l}\text { Depew et al. } \\
\text { (2012) }\end{array}$ \\
\hline Reproduction & Severe impaired productivity & 3.4 & $\begin{array}{l}\text { Diet } \\
\text { (fish) }\end{array}$ & 0.40 & $\mu \mathrm{g} / \mathrm{g} \mathrm{ww}$ & Common Loon & Barr (1986) \\
\hline Reproduction & Decreased egg hatchability & 3.5 & Egg & 1.50 & $\mu \mathrm{g} / \mathrm{g} \mathrm{ww}$ & $\begin{array}{l}\text { Ring-necked } \\
\text { Pheasant }\end{array}$ & Fimreite (1971) \\
\hline Reproduction & $\begin{array}{l}\text { Decreased productivity for first } \\
\text { time breeding females (in } 1 \text { of } 2 \\
\text { years of study; mean of } \\
\text { contaminated site) }\end{array}$ & 3.6 & Blood & 3.56 & $\mu \mathrm{g} / \mathrm{g}$ ww & Tree Swallow & $\begin{array}{l}\text { Brasso and Cristol } \\
\text { (2008) }\end{array}$ \\
\hline Reproduction & $\begin{array}{l}30 \% \text { probability of embryo being } \\
\text { malpositioned in egg }\end{array}$ & 3.6 & Egg & 1.55 & $\mu \mathrm{g} / \mathrm{g}$ fww & Forster's Tern & $\begin{array}{l}\text { Herring et al. } \\
\qquad(2010)\end{array}$ \\
\hline
\end{tabular}




\begin{tabular}{|c|c|c|c|c|c|c|c|c|}
\hline Reproduction & $\begin{array}{l}14 \% \text { decrease in productive nests; } \\
\text { altered courtship behaviors; higher } \\
\text { proportion of same sex nest pairs } \\
\text { (mean of dosed birds) }\end{array}$ & 4.0 & Blood & 3.95 & $\mu \mathrm{g} / \mathrm{g} w \mathrm{w}$ & White Ibis & $\begin{array}{c}\text { Frederick and } \\
\text { Jayasena }(2010)^{\mathrm{a}}\end{array}$ & na \\
\hline Reproduction & $\begin{array}{l}40 \% \text { probability of embryo being } \\
\text { malpositioned in egg }\end{array}$ & 4.0 & Egg & 1.69 & $\mu \mathrm{g} / \mathrm{g}$ fww & Forster's Tern & $\begin{array}{l}\text { Herring et al. } \\
\quad(2010)\end{array}$ & 3 \\
\hline Reproduction & $\begin{array}{l}46 \% \text { reduction in max. } \\
\text { productivity }\end{array}$ & 4.0 & Blood & 4.00 & $\mu \mathrm{g} / \mathrm{g} w \mathrm{w}$ & Common Loon & $\begin{array}{l}\text { Burgess and Meyer } \\
\text { (2008) }\end{array}$ & na \\
\hline Reproduction & $\begin{array}{l}16 \% \text { reduction in reproductive } \\
\text { success }\end{array}$ & 4.0 & Blood & 4.00 & $\mu \mathrm{g} / \mathrm{g} w \mathrm{w}$ & Zebra Finch & $\begin{array}{l}\text { Varian-Ramos et } \\
\text { al. }(2014)^{\mathrm{a}}\end{array}$ & na \\
\hline Reproduction & $\begin{array}{l}\text { Egg hatchability: } \mathrm{LC}_{50} \text { of egg- } \\
\text { injected and maternally derived } \\
\text { MeHg }\end{array}$ & 4.2 & Egg & 1.78 & $\mu \mathrm{g} / \mathrm{g} w \mathrm{w}$ & Common Loon & $\begin{array}{l}\text { Kenow et al. } \\
\quad(2011)^{\mathrm{a}}\end{array}$ & 3 \\
\hline Reproduction & $\begin{array}{l}\text { Egg hatchability: } \mathrm{LC}_{50} \text { of egg- } \\
\text { injected birds ranked as low } \\
\text { sensitivity to } \mathrm{MeHg}\end{array}$ & 4.2 & Egg & 1.79 & $\mu \mathrm{g} / \mathrm{g} w \mathrm{w}$ & Multiple & $\begin{array}{l}\text { Heinz et al. } \\
(2009 a)^{\mathrm{a}}\end{array}$ & 3 \\
\hline Reproduction & $\begin{array}{l}50 \% \text { probability of embryo being } \\
\text { malpositioned in egg }\end{array}$ & 4.3 & Egg & 1.82 & $\mu \mathrm{g} / \mathrm{g}$ fww & Forster's Tern & $\begin{array}{l}\text { Herring et al. } \\
\quad(2010)\end{array}$ & 3 \\
\hline Reproduction & $\begin{array}{l}50 \% \text { reduction in max. } \\
\text { productivity }\end{array}$ & 4.3 & Blood & 4.30 & $\mu \mathrm{g} / \mathrm{g} w \mathrm{w}$ & Common Loon & $\begin{array}{l}\text { Burgess and Meyer } \\
\text { (2008) }\end{array}$ & na \\
\hline Reproduction & $\begin{array}{l}\text { Decreased egg hatchability (mean } \\
\text { of contaminated site) }\end{array}$ & 4.3 & Egg & 7.34 & $\mu \mathrm{g} / \mathrm{g} \mathrm{dw}$ & Tree Swallow & Custer et al. (2007) & 3 \\
\hline $\begin{array}{l}\text { Health and } \\
\text { physiology }\end{array}$ & $\begin{array}{l}\text { Glutathione metabolism and } \\
\text { antioxidant activity (effect on } \\
\text { associated enzymes below this } \\
\text { concentration) }^{\mathrm{d}}\end{array}$ & 4.6 & Liver & 35.00 & $\mu \mathrm{g} / \mathrm{g} \mathrm{dw}$ & Surf Scoter & $\begin{array}{l}\text { Hoffman et al. } \\
\text { (1998) }\end{array}$ & 1 \\
\hline Reproduction & $\begin{array}{l}24 \% \text { decline in young fledged per } \\
\text { pair (over this concentration) }\end{array}$ & 4.8 & Egg & 2.00 & $\mu \mathrm{g} / \mathrm{g} w \mathrm{w}$ & American Kestrel & $\begin{array}{l}\text { Albers et al. } \\
\qquad(2007)^{\mathrm{a}}\end{array}$ & 3 \\
\hline $\begin{array}{l}\text { Health and } \\
\text { physiology }\end{array}$ & $\begin{array}{l}\text { Impaired macrophage } \\
\text { phagocytosis (below this } \\
\text { concentration) }^{\mathrm{d}}\end{array}$ & 6.4 & Blood & 6.40 & $\mu \mathrm{g} / \mathrm{g} w \mathrm{w}$ & $\begin{array}{l}\text { Black-footed } \\
\text { Albatross }\end{array}$ & $\begin{array}{l}\text { Finkelstein et al. } \\
\text { (2007) }\end{array}$ & na \\
\hline Reproduction & $\begin{array}{l}\text { Decreased offspring survival } \\
\text { (mean of dosed birds) }\end{array}$ & 6.6 & Muscle & 4.50 & $\mu \mathrm{g} / \mathrm{g} \mathrm{ww}$ & Black Duck & $\begin{array}{l}\text { Finley and Stendell } \\
\qquad(1978)^{\mathrm{a}}\end{array}$ & 5 \\
\hline
\end{tabular}




\begin{tabular}{|c|c|c|c|c|c|c|c|c|}
\hline Reproduction & $\begin{array}{l}31 \% \text { reduction in reproductive } \\
\text { success, greater number of days to } \\
\text { renesting (mean of dosed birds) }\end{array}$ & 8.0 & Blood & 8.00 & $\mu \mathrm{g} / \mathrm{g} \mathrm{ww}$ & Zebra Finch & $\begin{array}{l}\text { Varian-Ramos et } \\
\text { al. }(2014)^{\mathrm{a}}\end{array}$ & na \\
\hline $\begin{array}{l}\text { Health and } \\
\text { physiology }\end{array}$ & $\begin{array}{l}\text { Glutathione metabolism and } \\
\text { antioxidant activity (effect on } \\
\text { associated enzymes below this } \\
\text { concentration) }\end{array}$ & 8.5 & Liver & 66.00 & $\mu \mathrm{g} / \mathrm{g} \mathrm{dw}$ & Greater Scaup & $\begin{array}{l}\text { Hoffman et al. } \\
\qquad(1998)\end{array}$ & 1 \\
\hline Mortality & $\begin{array}{l}\text { Proposed indicative concentration } \\
\text { for death (review) }\end{array}$ & 8.5 & Liver & 22.00 & $\mu \mathrm{g} / \mathrm{g} w \mathrm{w}$ & Multiple & Shore et al. (2011) & 1 \\
\hline $\begin{array}{l}\text { Health and } \\
\text { physiology }\end{array}$ & $\begin{array}{l}\text { Effects on some bioindicators of } \\
\text { oxidative stress (below this } \\
\text { concentration) }\end{array}$ & 8.8 & Liver & 69.00 & $\mu \mathrm{g} / \mathrm{g} \mathrm{dw}$ & $\begin{array}{l}\text { Forster's Tern, } \\
\text { Caspian Tern }\end{array}$ & $\begin{array}{l}\text { Hoffman et al. } \\
\qquad(2011)\end{array}$ & 1 \\
\hline Reproduction & $\begin{array}{l}\text { Decreased offspring survival } \\
\text { (mean of dosed birds) }\end{array}$ & 9.0 & Liver & 23.10 & $\mu \mathrm{g} / \mathrm{g} w \mathrm{w}$ & Black Duck & $\begin{array}{l}\text { Finley and Stendell } \\
\qquad(1978)^{\mathrm{a}}\end{array}$ & 1 \\
\hline Reproduction & $\begin{array}{l}\text { Reproductive impairment (mean } \\
\text { from lake with decreased } \\
\text { reproduction) }\end{array}$ & 9.1 & Egg & 3.65 & $\mu \mathrm{g} / \mathrm{g} w \mathrm{w}$ & Common Tern & Fimreite (1974) & 3 \\
\hline $\begin{array}{l}\text { Health and } \\
\text { physiology }\end{array}$ & $\begin{array}{l}\text { Decreased energy expenditure for } \\
\text { flight takeoff; altered molt } \\
\text { sequence (mean of dosed birds) }\end{array}$ & 9.8 & Blood & 9.80 & $\mu \mathrm{g} / \mathrm{g} \mathrm{ww}$ & European Starling & $\begin{array}{l}\text { Carlson et al. } \\
\qquad(2014)^{\mathrm{a}}\end{array}$ & na \\
\hline Mortality & $\begin{array}{l}\text { Proposed concentration for } \\
\text { mercury toxicity (review) }\end{array}$ & 11.5 & Liver & 30.00 & $\mu \mathrm{g} / \mathrm{g} w \mathrm{w}$ & Multiple & Thompson (1996) & 1 \\
\hline Reproduction & $\begin{array}{l}\text { Lethality to embryo (mean of eggs } \\
\text { from dosed females) }\end{array}$ & 13.0 & Egg & 5.10 & $\mu \mathrm{g} / \mathrm{g} w \mathrm{w}$ & Black Duck & $\begin{array}{l}\text { Finley and Stendell } \\
\qquad(1978)^{\mathrm{a}} ; \text { from } \\
\text { Shore et al. }(2011)\end{array}$ & 3 \\
\hline Behavioral & $\begin{array}{l}\text { Mass loss and altered foraging } \\
\text { behavior in response to simulated } \\
\text { predator (mean of dosed birds) }\end{array}$ & 13.9 & Blood & 13.93 & $\mu \mathrm{g} / \mathrm{g} \mathrm{ww}$ & Zebra Finch & $\begin{array}{l}\text { Kobiela et al. } \\
\qquad(2015)^{\mathrm{a}}\end{array}$ & na \\
\hline Behavioral & $\begin{array}{l}\text { Visible neurotoxicity; impaired } \\
\text { movement (mean of dosed birds) }\end{array}$ & 16.4 & Liver & 43.00 & $\mu \mathrm{g} / \mathrm{g} w \mathrm{w}$ & Zebra Finch & $\begin{array}{l}\text { Scheuhammer } \\
\quad(1988)^{\mathrm{a}}\end{array}$ & $1^{\mathrm{e}}$ \\
\hline Reproduction & $\begin{array}{l}42 \% \text { reduction in reproductive } \\
\text { success, greater number of days to } \\
\text { renesting (mean of dosed birds) }\end{array}$ & 17.0 & Blood & 17.00 & $\mu \mathrm{g} / \mathrm{g} w \mathrm{w}$ & Zebra Finch & $\begin{array}{l}\text { Varian-Ramos et } \\
\text { al. }(2014)^{\mathrm{a}}\end{array}$ & na \\
\hline
\end{tabular}




\begin{tabular}{|c|c|c|c|c|c|c|c|c|}
\hline Mortality & $\begin{array}{l}\text { Death; swelling of axons; loss of } \\
\text { myelin (below this concentration) }\end{array}$ & 18.1 & Muscle & 11.40 & $\mu \mathrm{g} / \mathrm{g}$ & Red-tailed Hawk & $\begin{array}{c}\text { Fimreite and } \\
\text { Karstad }(1971)^{\mathrm{a}}\end{array}$ & $5^{\mathrm{e}}$ \\
\hline Mortality & $\begin{array}{l}\text { Death (mean concentration for } \\
\text { dead birds: review) }\end{array}$ & 23.7 & Liver & 63.00 & $\mu \mathrm{g} / \mathrm{g} \mathrm{ww}$ & Multiple & Shore et al. (2011) & $1^{\mathrm{e}}$ \\
\hline $\begin{array}{l}\text { Health and } \\
\text { physiology }\end{array}$ & $\begin{array}{l}\text { Decreased enzymes associated } \\
\text { with oxidative stress (mean of } \\
\text { dosed birds) }\end{array}$ & 24.4 & Liver & 65.00 & $\mu \mathrm{g} / \mathrm{g} \mathrm{ww}$ & Mallard & $\begin{array}{l}\text { Hoffman and } \\
\text { Heinz }(1998)^{\mathrm{a}}\end{array}$ & $1^{\mathrm{e}}$ \\
\hline Mortality & $\begin{array}{l}\text { Death (mean of dosed birds that } \\
\text { died) }\end{array}$ & 27.3 & Liver & 73.00 & $\mu \mathrm{g} / \mathrm{g} \mathrm{ww}$ & Zebra Finch & $\begin{array}{l}\text { Scheuhammer } \\
\quad(1988)^{\mathrm{a}}\end{array}$ & $1^{\mathrm{e}}$ \\
\hline Reproduction & $\begin{array}{l}50 \% \text { reduction in reproductive } \\
\text { success, greater number of days to } \\
\text { renesting (mean of dosed birds) }\end{array}$ & 31.0 & Blood & 31.00 & $\mu \mathrm{g} / \mathrm{g} w \mathrm{w}$ & Zebra Finch & $\begin{array}{l}\text { Varian-Ramos et } \\
\text { al. }(2014)^{\mathrm{a}}\end{array}$ & na \\
\hline $\begin{array}{l}\text { Health and } \\
\text { physiology }\end{array}$ & $\begin{array}{l}\text { Acute inflammatory response; } \\
\text { physiological stress (mean of } \\
\text { dosed birds) }\end{array}$ & 41.7 & Blood & 41.71 & $\mu \mathrm{g} / \mathrm{g} w \mathrm{w}$ & American Kestrel & $\begin{array}{l}\text { Fallacara et al. } \\
\qquad(2011)^{\mathrm{a}}\end{array}$ & na \\
\hline Mortality & $\begin{array}{l}\text { Visible neurotoxicity; some death } \\
\text { (mean of dosed birds) }\end{array}$ & 45.0 & Blood & 45.00 & $\mu \mathrm{g} / \mathrm{g} \mathrm{ww}$ & American Kestrel & $\begin{array}{l}\text { Bennett et al. } \\
\qquad(2009)^{\mathrm{a}}\end{array}$ & na \\
\hline $\begin{array}{l}\text { Health and } \\
\text { physiology }\end{array}$ & $\begin{array}{l}\text { Effects on brain neurotransmitters } \\
\text { (below this concentration) }^{\mathrm{d}}\end{array}$ & 48.2 & Liver & 397.00 & $\mu \mathrm{g} / \mathrm{g} \mathrm{dw}$ & Bald Eagle & $\begin{array}{l}\text { Scheuhammer et al. } \\
\text { (2008) }\end{array}$ & $1^{\mathrm{e}}$ \\
\hline Mortality & $\begin{array}{l}\text { Death (mean of dosed birds that } \\
\text { died) }\end{array}$ & 51.4 & Muscle & 30.00 & $\mu \mathrm{g} / \mathrm{g} w \mathrm{w}$ & Grackle & $\begin{array}{l}\text { Finley et al. } \\
\qquad(1979)^{\mathrm{a}}\end{array}$ & $5^{\mathrm{e}}$ \\
\hline Mortality & $\begin{array}{l}\text { Death (mean of dosed birds that } \\
\text { died) }\end{array}$ & 54.2 & Muscle & 31.50 & $\mu \mathrm{g} / \mathrm{g} \mathrm{ww}$ & Cowbird & $\begin{array}{l}\text { Finley et al. } \\
\qquad(1979)^{\mathrm{a}}\end{array}$ & $5^{\mathrm{e}}$ \\
\hline $\begin{array}{l}\text { Health and } \\
\text { physiology }\end{array}$ & $\begin{array}{l}\text { Decreased ability to mount a stress } \\
\text { response (below this } \\
\text { concentration) }^{\mathrm{d}}\end{array}$ & 57.0 & Blood & 57.00 & $\mu \mathrm{g} / \mathrm{g} w \mathrm{w}$ & Zebra Finch & $\begin{array}{l}\text { Moore et al. } \\
\qquad(2014)^{\mathrm{a}}\end{array}$ & na \\
\hline $\begin{array}{l}\text { Health and } \\
\text { physiology }\end{array}$ & $\begin{array}{l}\text { Effects on brain neurotransmitters } \\
\text { (below this concentration) }^{\mathrm{d}}\end{array}$ & 65.2 & Liver & 542.00 & $\mu \mathrm{g} / \mathrm{g} \mathrm{dw}$ & Common Loon & $\begin{array}{l}\text { Scheuhammer et al. } \\
\text { (2008) }\end{array}$ & $1^{\mathrm{e}}$ \\
\hline Mortality & $\begin{array}{l}\text { Death (mean of dosed birds that } \\
\text { died) }\end{array}$ & 71.4 & Muscle & 40.70 & $\mu \mathrm{g} / \mathrm{g} \mathrm{ww}$ & Starling & $\begin{array}{l}\text { Finley et al. } \\
\qquad(1979)^{\mathrm{a}}\end{array}$ & $5^{\mathrm{e}}$ \\
\hline Mortality & $\begin{array}{l}\text { Death (mean of dosed birds that } \\
\text { died) }\end{array}$ & 94.0 & Blood & 94.00 & $\mu \mathrm{g} / \mathrm{g} \mathrm{ww}$ & American Kestrel & $\begin{array}{l}\text { Bennett et al. } \\
\qquad(2009)^{\mathrm{a}}\end{array}$ & na \\
\hline
\end{tabular}


a Indicates a captive feeding study with dosed birds.

${ }^{\mathrm{b}}$ Equations used to translate toxicity benchmark to bird blood-equivalent units:

(eq 1) $\ln \left(\right.$ Blood $\left.T H g_{\frac{\mu g}{g} w w}\right)=0.970 \times \ln \left(\right.$ Bird Liver THg $\left.\frac{\mu g}{g} d w\right)-1.929 \quad\left(\mathrm{R}^{2}=0.88\right.$; Eagles-Smith et al., 2008)

(eq 2) Results for THg concentrations in red blood cells were reported as $\mu \mathrm{g} / \mathrm{g} \mathrm{dw}$, without any estimate of percent moisture available. Therefore, we assumed a percent moisture of $79 \%$ (see Eagles-Smith et al., 2008) to convert $\mu \mathrm{g} / \mathrm{g}$ dw to $\mu \mathrm{g} / \mathrm{g}$ ww.

(eq 3) $\ln \left(\right.$ Female Bird Blood THg $\left.\frac{\mu g}{g}_{w w}\right)=1.0734 \times \ln \left(E g g\right.$ THg $\left.g_{\frac{\mu g}{g}} f w w\right)+0.8149\left(\mathrm{R}^{2}=0.95\right.$; Ackerman et al., 2016a)

(eq 4) $\ln \left(\right.$ Female Bird Blood THg $\left.\frac{\mu g}{g}_{\frac{g}{} w}\right)=0.6182 \times \ln \left(\right.$ Prey Fish THg $\left.\frac{\mu \mathrm{\mu g}}{g} w w\right)+1.788$ (Ackerman et al., 2015)

(eq 5) $\ln \left(\right.$ Blood THg $\left.\frac{\mu g}{g} w w\right)=1.080 \times \ln \left(\right.$ Bird Muscle THg $\left.\frac{\mu g}{g} d w\right)-1.024 \quad\left(\mathrm{R}^{2}=0.90\right.$; Eagles-Smith et al., 2008)

${ }^{c}$ Moisture content from the study was used if reported. If it was not reported, a moisture content of $67 \%$ in liver, $75 \%$ in eggs, $70 \%$ in muscle, and $79 \%$ in blood was used (Eagles-Smith et al., 2008). If wet weight vs dry weight was not reported, wet weight (muscle) was assumed.

${ }^{\mathrm{d}}$ For correlative studies with a relationship between THg concentration and an effect, the highest observed THg concentration was reported and stated that the relationship was observed "below this concentration."

${ }^{\mathrm{e}} \mathrm{THg}$ concentrations in these captive studies had highly-dosed birds with liver or muscle THg concentrations outside of the range of data used to generate the equations to translate tissue $\mathrm{THg}$ concentrations to blood-equivalent units, and blood-equivalent $\mathrm{THg}$ concentrations should be interpreted with caution. 
Table 2. Suggested tissues for sampling bird mercury contamination.

\begin{tabular}{|c|c|c|c|c|c|c|c|}
\hline Priority & Age & Tissue & $\begin{array}{l}\text { Mercury } \\
\text { Analysis }\end{array}$ & $\begin{array}{l}\text { Most } \\
\mathrm{THg} \text { in } \\
\mathrm{MeHg} \\
\text { form? }\end{array}$ & Units & Represents & Reference \\
\hline High & Adult & Blood & $\mathrm{THg}$ & Yes & $\begin{array}{l}\text { wet weight or } \\
\text { dry weight }\end{array}$ & $\begin{array}{l}\mathrm{Hg} \text { in adult and egg (if a } \\
\text { breeding female) }\end{array}$ & $\begin{array}{l}\text { Henny et al. (2002); Evers et al. } \\
\text { (2003); Rimmer et al. (2005); } \\
\text { Eagles-Smith et al. (2008); } \\
\text { Brasso et al. (2010); Heinz et } \\
\text { al. (2010); Kenow et al. (2015); } \\
\text { Ou et al. (2015); Ackerman et } \\
\text { al. (2016a) }\end{array}$ \\
\hline High & Egg & Eggs & $\mathrm{THg}$ & Yes & $\begin{array}{l}\text { fresh wet } \\
\text { weight }\end{array}$ & $\begin{array}{l}\mathrm{Hg} \text { in egg and adult; direct link } \\
\text { to reproduction }\end{array}$ & $\begin{array}{l}\text { Ackerman et al. (2013); } \\
\text { Ackerman et al. (2016a) }\end{array}$ \\
\hline High & Chick & $\begin{array}{l}\text { Feathers } \\
\text { (down) }\end{array}$ & $\mathrm{THg}$ & Yes & dry weight & $\mathrm{Hg}$ in egg; highly correlated & $\begin{array}{l}\text { Ackerman and Eagles-Smith } \\
\text { (2009); Kenow et al. (2011) }\end{array}$ \\
\hline Moderate & Egg & Egg albumen & $\mathrm{THg}$ & Yes & wet weight & $\begin{array}{l}\mathrm{Hg} \text { in whole egg; direct link to } \\
\text { reproduction }\end{array}$ & $\begin{array}{l}\text { Kennamer et al. (2005); Bond } \\
\text { and Diamond (2009); Stebbins } \\
\text { et al. (2009) }\end{array}$ \\
\hline Moderate & Adult & Muscle & $\mathrm{THg}$ & Yes & dry weight & $\begin{array}{l}\mathrm{Hg} \text { in adult and egg (if a } \\
\text { breeding female) }\end{array}$ & $\begin{array}{l}\text { Finley and Stendell (1978); } \\
\text { Scheuhammer et al. (1998); } \\
\text { Eagles-Smith et al. (2008); } \\
\text { Ackerman et al. (2016a) }\end{array}$ \\
\hline Moderate & Adult & Liver & $\mathrm{MeHg}$ & No & dry weight & $\begin{array}{l}\mathrm{Hg} \text { in adult and egg (if a } \\
\text { breeding female) }\end{array}$ & $\begin{array}{l}\text { Finley and Stendell (1978); } \\
\text { Henny et al. (2002); Eagles- } \\
\text { Smith et al. (2008); Eagles- } \\
\text { Smith et al. (2009b); Ackerman } \\
\text { et al. (2016a) }\end{array}$ \\
\hline Moderate & Adult & Kidney & $\mathrm{MeHg}$ & No & dry weight & $\begin{array}{l}\mathrm{Hg} \text { in adult and egg (if a } \\
\text { breeding female) }\end{array}$ & $\begin{array}{l}\text { Finley and Stendell (1978); } \\
\text { Henny et al. (2002); Eagles- } \\
\text { Smith et al. (2008); Ackerman } \\
\text { et al. (2016a) }\end{array}$ \\
\hline Moderate & Adult & Brain & $\mathrm{MeHg}$ & No & dry weight & $\mathrm{Hg}$ in adult & $\begin{array}{l}\text { Finley and Stendell (1978); } \\
\text { Scheuhammer et al. (2008) }\end{array}$ \\
\hline
\end{tabular}




\begin{tabular}{|c|c|c|c|c|c|c|c|}
\hline Low & Adult & $\begin{array}{l}\text { Feathers } \\
\text { (fully-grown) }\end{array}$ & $\mathrm{THg}$ & Yes & dry weight & $\begin{array}{l}\text { Poor correlation with } \mathrm{Hg} \text { in } \\
\text { internal tissues and eggs for } \\
\text { most birds; exceptions are for } \\
\text { species with limited movements }\end{array}$ & $\begin{array}{l}\text { Thompson and Furness (1989); } \\
\text { Brasso and Cristol (2008); } \\
\text { Eagles-Smith et al. (2008); } \\
\text { Jackson et al. (2011); } \\
\text { Ackerman et al. (2012); } \\
\text { Ackerman et al. (2016a) }\end{array}$ \\
\hline Low & Egg & Egg yolk & $\mathrm{THg}$ & Yes & wet weight & $\begin{array}{l}\mathrm{Hg} \text { in whole egg; moderate } \\
\text { correlation }\end{array}$ & $\begin{array}{l}\text { Kennamer et al. (2005); Bond } \\
\text { and Diamond (2009) }\end{array}$ \\
\hline Low & Egg & Egg shell & $\mathrm{THg}$ & Unknown & dry weight & $\begin{array}{l}\mathrm{Hg} \text { in whole egg; moderate } \\
\text { correlation }\end{array}$ & Kennamer et al. (2005) \\
\hline Low & Chick & Blood & $\mathrm{THg}$ & Yes & $\begin{array}{l}\text { wet weight or } \\
\text { dry weight }\end{array}$ & $\begin{array}{l}\mathrm{Hg} \text { changes rapidly with chick } \\
\text { age }\end{array}$ & $\begin{array}{l}\text { Kenow et al. (2007); Ackerman } \\
\text { et al. (2011) }\end{array}$ \\
\hline Extra Low & Chick & $\begin{array}{l}\text { Feathers } \\
\text { (fully-grown) }\end{array}$ & $\mathrm{THg}$ & Yes & dry weight & $\begin{array}{l}\text { Very poor correlation with } \mathrm{Hg} \\
\text { in internal tissues }\end{array}$ & Ackerman et al. (2009) \\
\hline Extra Low & Adult & $\begin{array}{l}\text { Feathers } \\
\text { (primary } \\
\text { flight } \\
\text { feathers) }\end{array}$ & $\mathrm{THg}$ & Yes & dry weight & $\begin{array}{l}\text { Very poor correlation with } \mathrm{Hg} \\
\text { in internal tissues; large } \\
\text { variability among feathers and } \\
\text { along length of feather }\end{array}$ & $\begin{array}{l}\text { Furness et al. (1986); Braune } \\
\text { and Gaskin (1987); Braune et } \\
\text { al. (1987); Dauwe et al. (2003) }\end{array}$ \\
\hline
\end{tabular}


Figure 1. Blood-equivalent total mercury ( $\mathrm{THg}$ ) concentrations in birds across western North America using (A) original data ( $n=27,629$ individual samples) and (B) mean data derived from a literature review ( $n=1,712$ means, representing $n=19,998$ individual samples). All (A) individual and (B) mean data points are shown, with lower THg concentrations as larger symbols in the background and higher $\mathrm{THg}$ concentrations as smaller symbols in the foreground. 

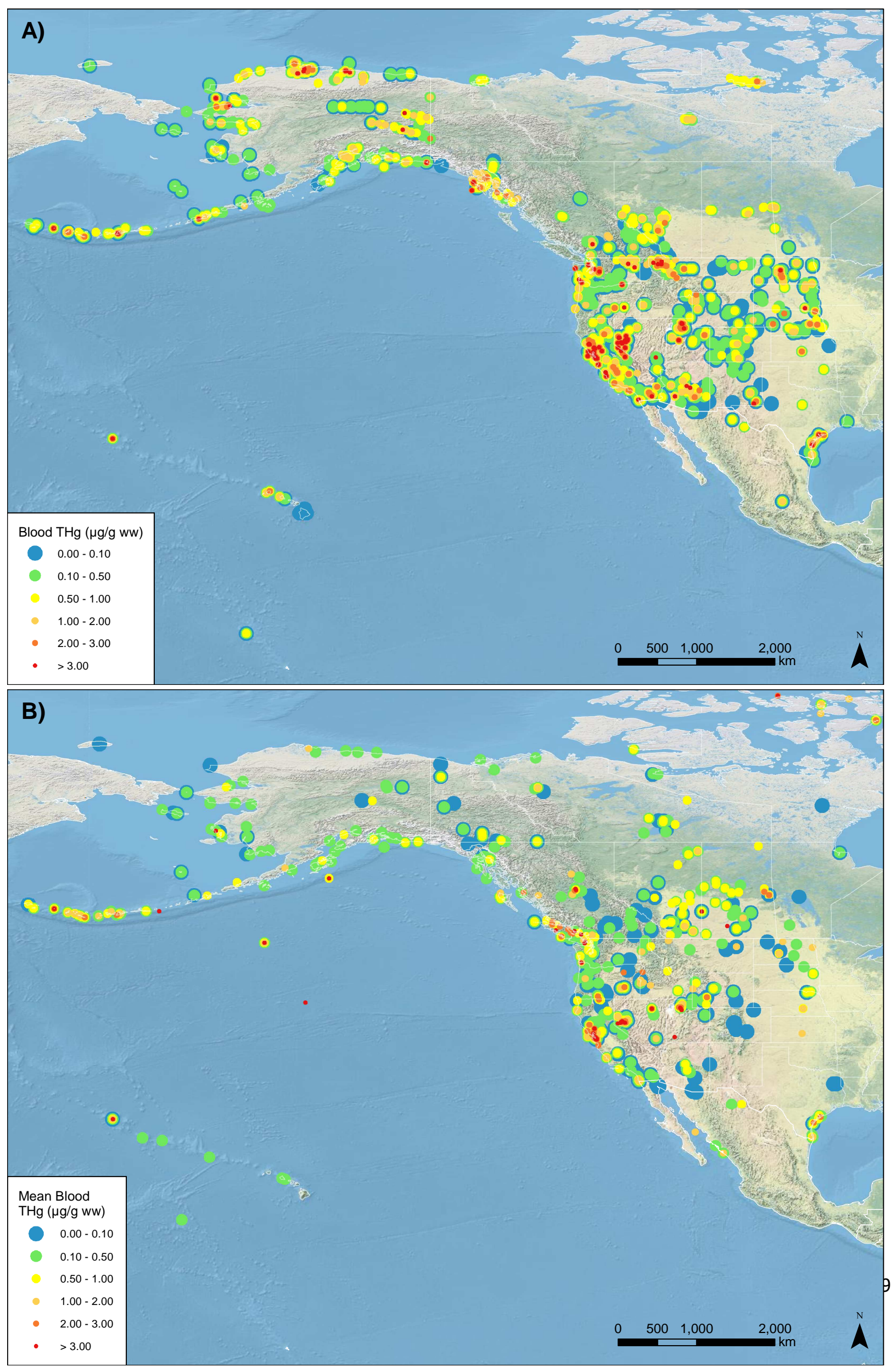
Figure 2. Least squares (LS) mean \pm standard error blood-equivalent total mercury (THg) concentrations in birds among (A) foraging guilds and (B) habitats in western North America using original data at the individual level (black-filled bars; $n=27,629$ individual samples) and mean data derived from a literature review (hatched bars; $n=1,712$ means, representing $n=19,998$ individual samples). LS mean blood-equivalent $\mathrm{THg}$ concentrations were estimated separately for each dataset from models with foraging guild, habitat, and ecoregion as fixed effects, and grid cell, year, and species as random effects. Different letters next to bars denote significant $(p<0.05)$ differences between means for the raw dataset (capital letters) and literature-review dataset (lower case letters).

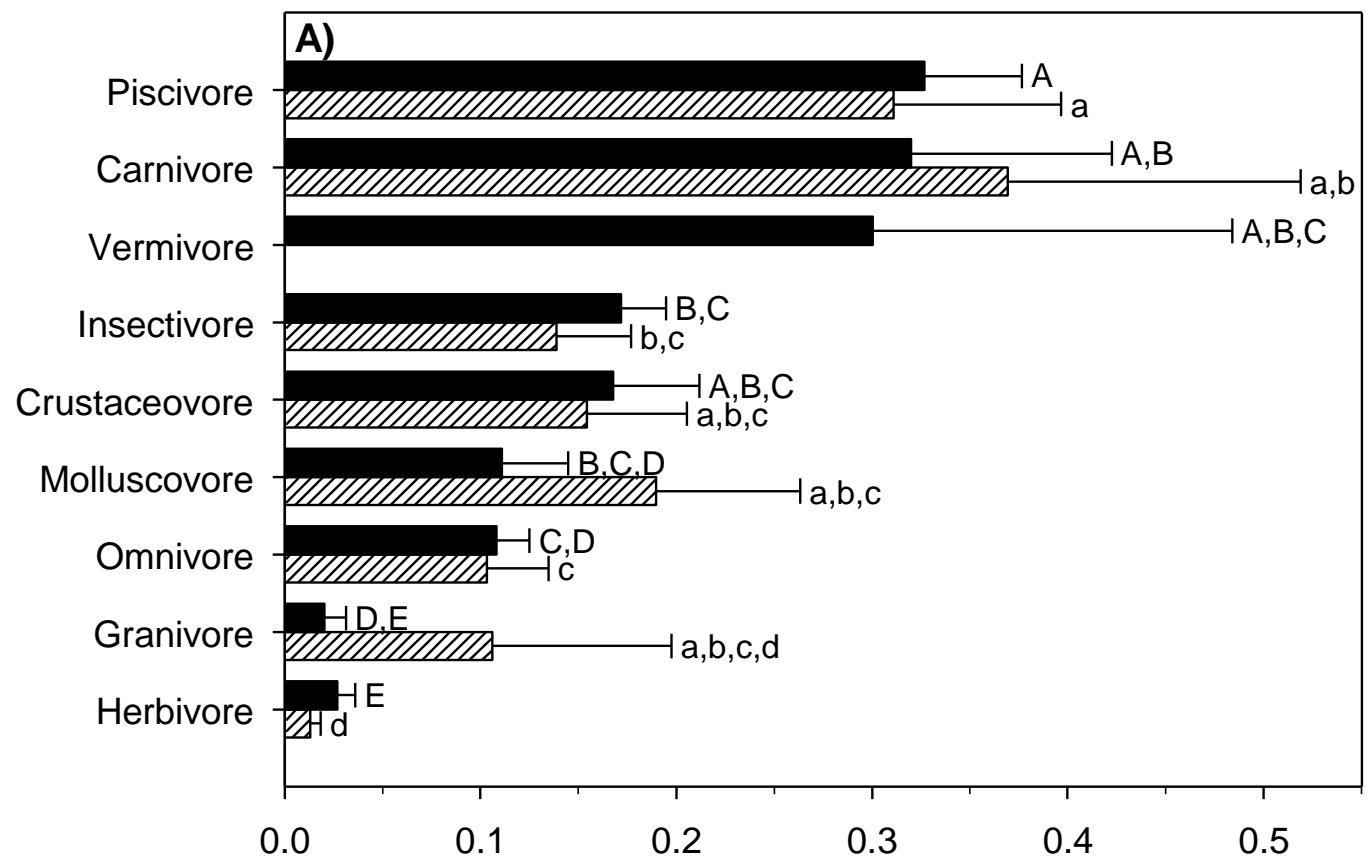

Blood-equivalent $\mathrm{THg}(\mu \mathrm{g} / \mathrm{g} \mathrm{ww})$

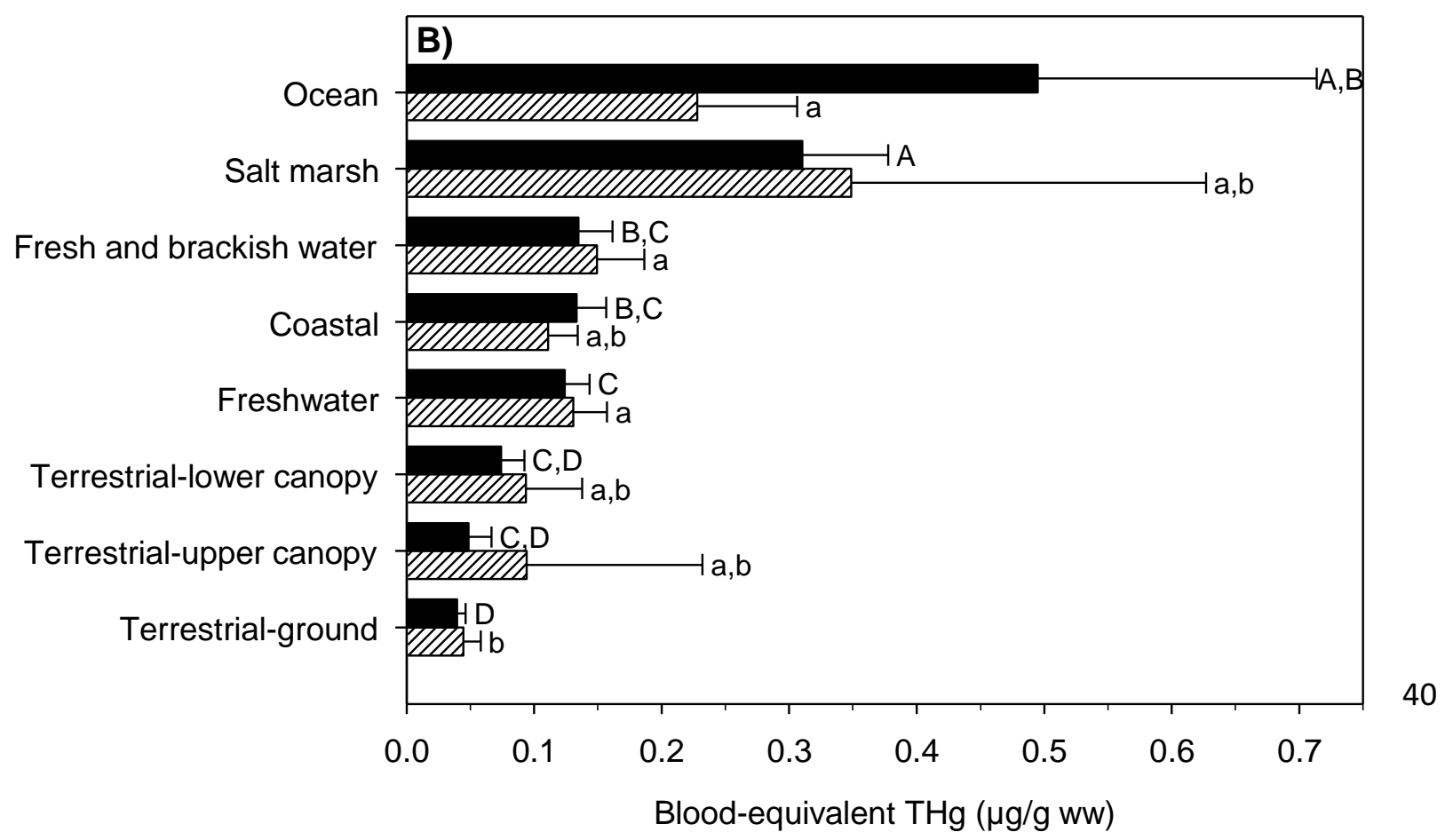


Figure 3. Least squares (LS) mean \pm standard error blood-equivalent total mercury (THg) concentrations among bird species in western North America using original data at the individual level. Only species with sample sizes $\geq 60$ are displayed; see Figures S2-S7 for a complete listing of species by taxanomic order. LS mean blood-equivalent THg concentrations were estimated from a model with species as a fixed effect, and grid cell and year as random effects.

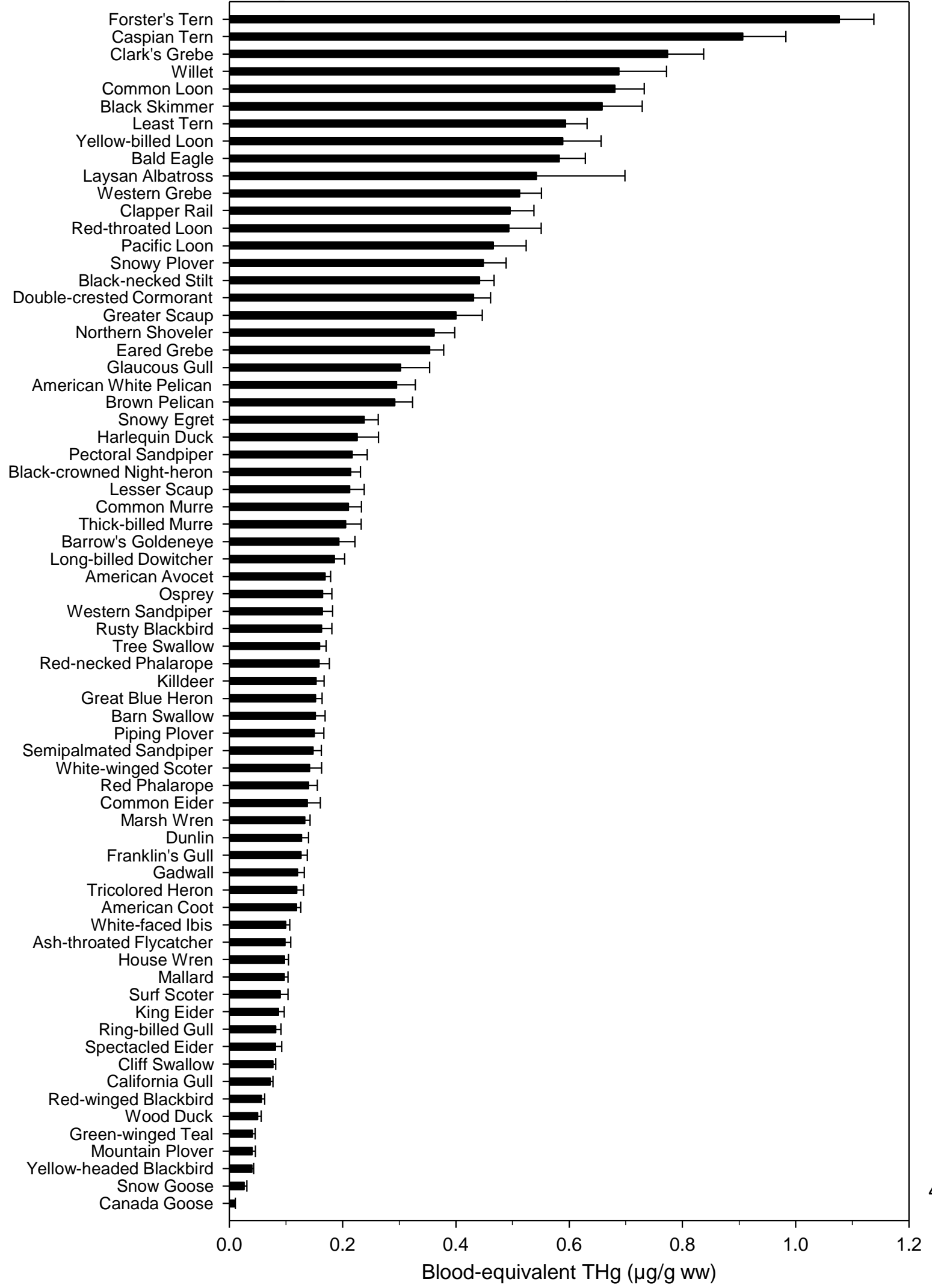




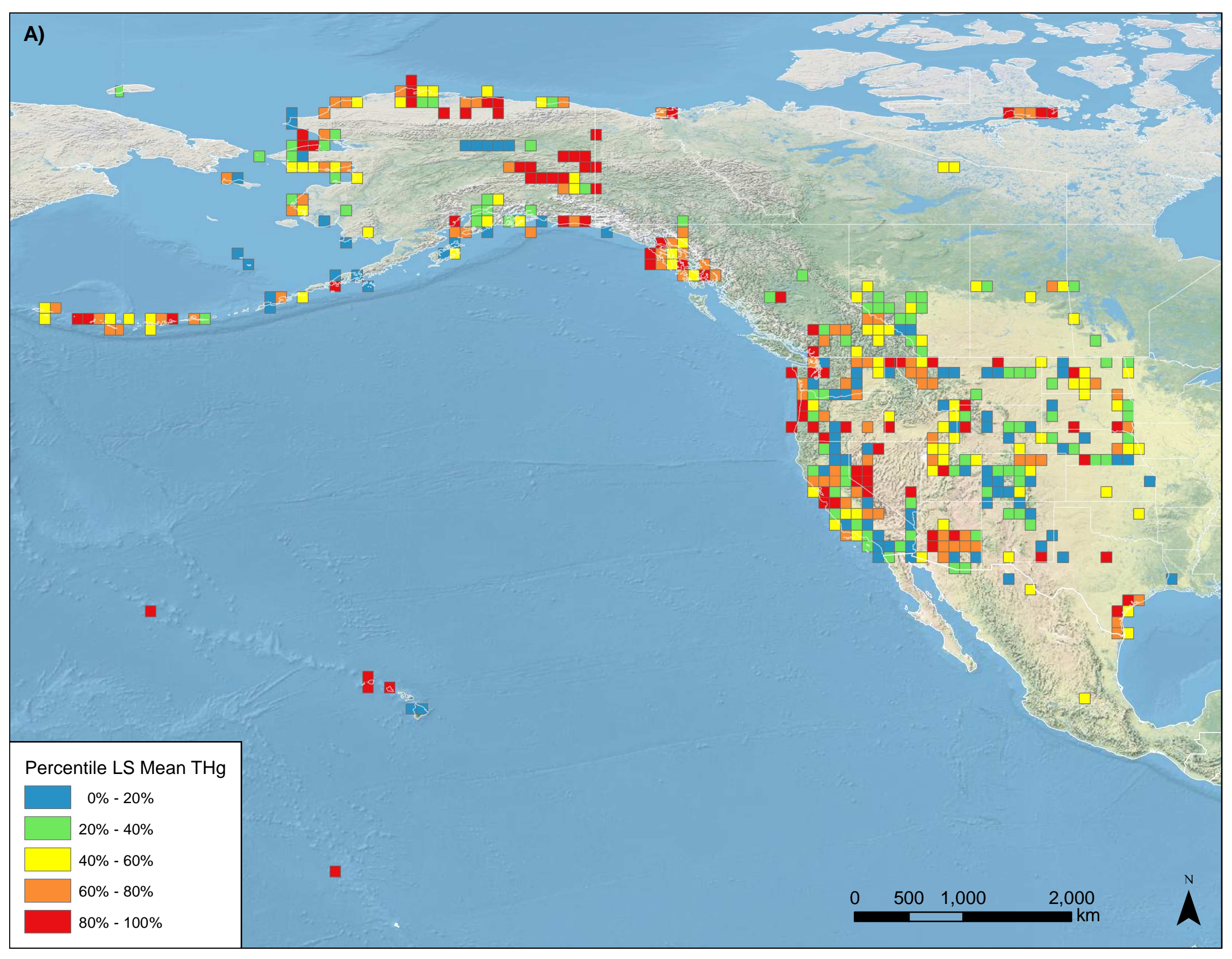


Figure 4. Blood-equivalent total mercury (THg) concentrations in birds across western North America using raw data ( $n=27,629$ individual samples). Each grid cell is $100 \mathrm{~km} \times 100 \mathrm{~km}$. (A) The large map on the opposite page displays grid cells by their percentile of least squares (LS) mean $\mathrm{THg}$ concentration relative to the entire dataset, such that $20 \%$ of all grid cells are represented by each color. LS mean $\mathrm{THg}$ concentrations were estimated from a model with grid cell as a fixed effect, and species and year as random effects. (B) Displays the sample size in each grid cell. (C) Displays the coefficient of variation (as a percentage) for the model-estimated LS mean $\mathrm{THg}$ concentration in each grid cell. The three maps can be used in combination to evaluate the confidence in the estimated bloodequivalent $\mathrm{THg}$ concentration in individual grid cells. The darker graduations indicate $(\mathbf{B})$ smaller sample sizes and $(\mathbf{C})$ greater coefficients of variation which denote lower confidence in the model-estimated LS mean $\mathrm{THg}$ concentrations in those grid cells.

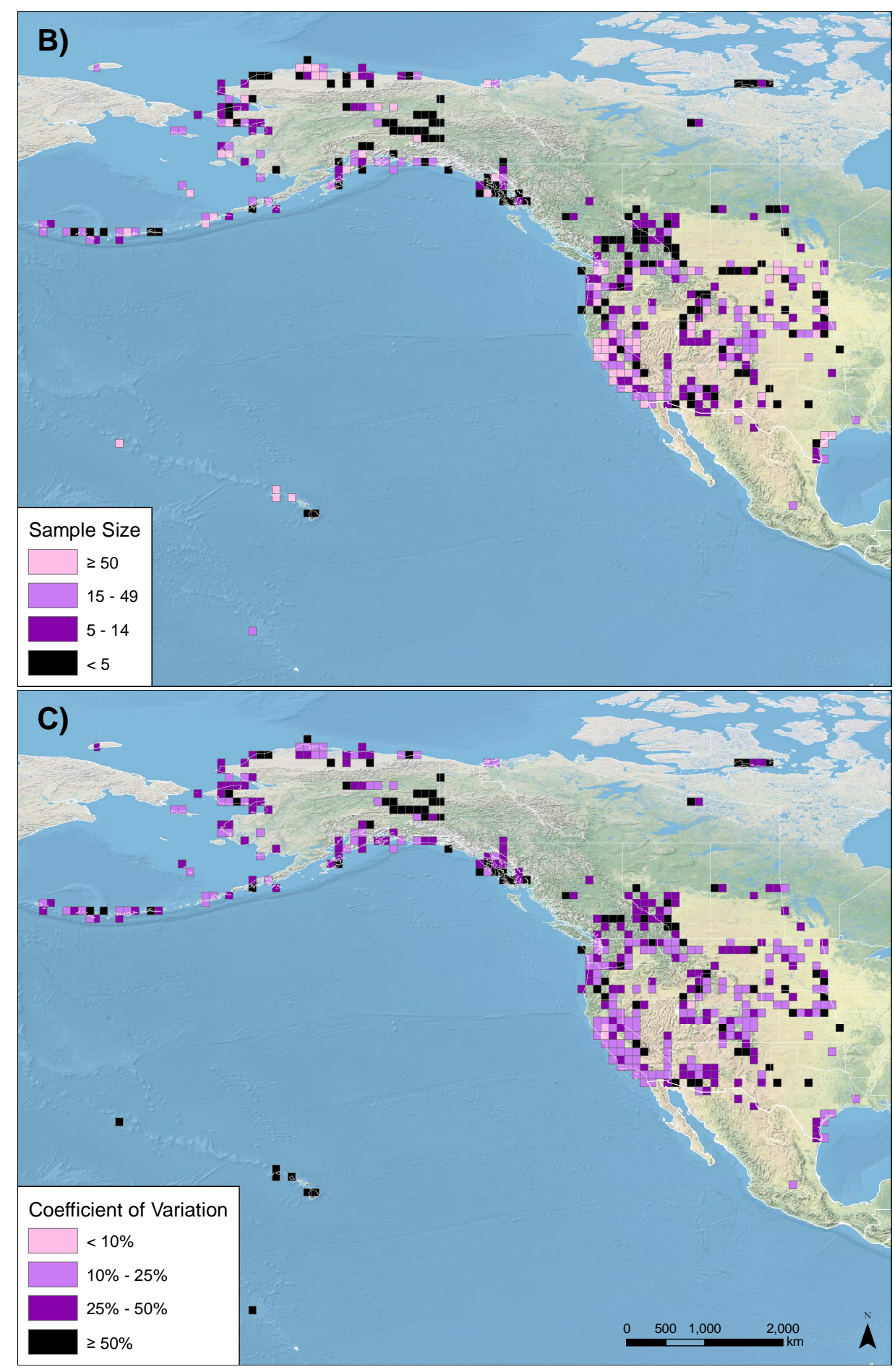



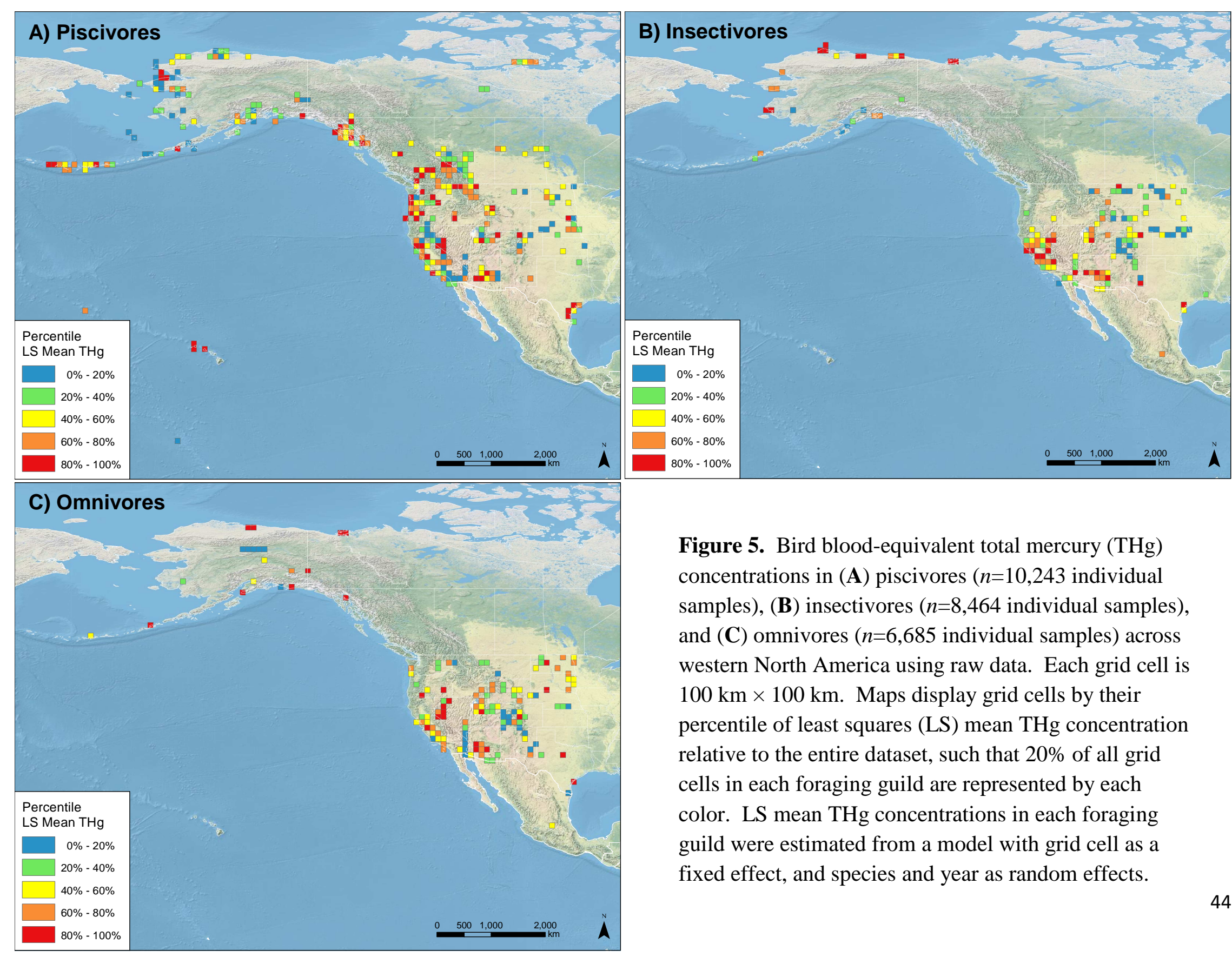

Figure 5. Bird blood-equivalent total mercury (THg) concentrations in (A) piscivores $(n=10,243$ individual samples), (B) insectivores ( $n=8,464$ individual samples), and (C) omnivores ( $n=6,685$ individual samples) across western North America using raw data. Each grid cell is $100 \mathrm{~km} \times 100 \mathrm{~km}$. Maps display grid cells by their percentile of least squares (LS) mean THg concentration relative to the entire dataset, such that $20 \%$ of all grid cells in each foraging guild are represented by each color. LS mean THg concentrations in each foraging guild were estimated from a model with grid cell as a fixed effect, and species and year as random effects. 
Figure 6. Least squares (LS) mean \pm standard error blood-equivalent total mercury (THg) concentrations in birds among ecoregions in western North America using data derived from a literature review ( $n=1,712$ means, representing $n=19,998$ individual samples). LS mean blood-equivalent THg concentrations were estimated from a model with foraging guild, habitat, and ecoregion as fixed effects, and grid cell, year, and species as random effects. Different lowercase letters next to bars denote significant $(p<0.05)$ differences between means. Literature-derived bird THg concentrations were available for 15 of the possible 17 ecoregions in western North America.

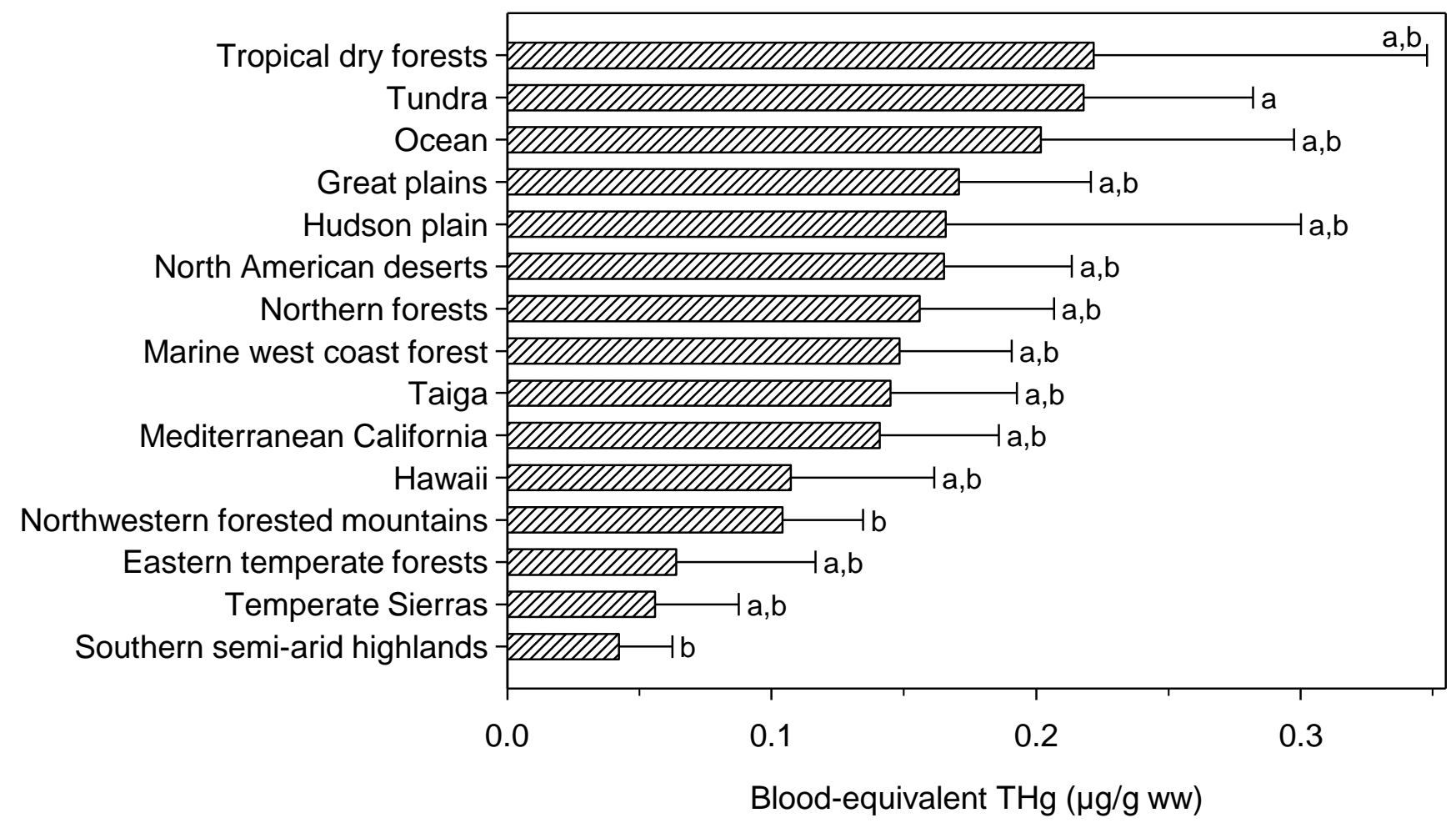




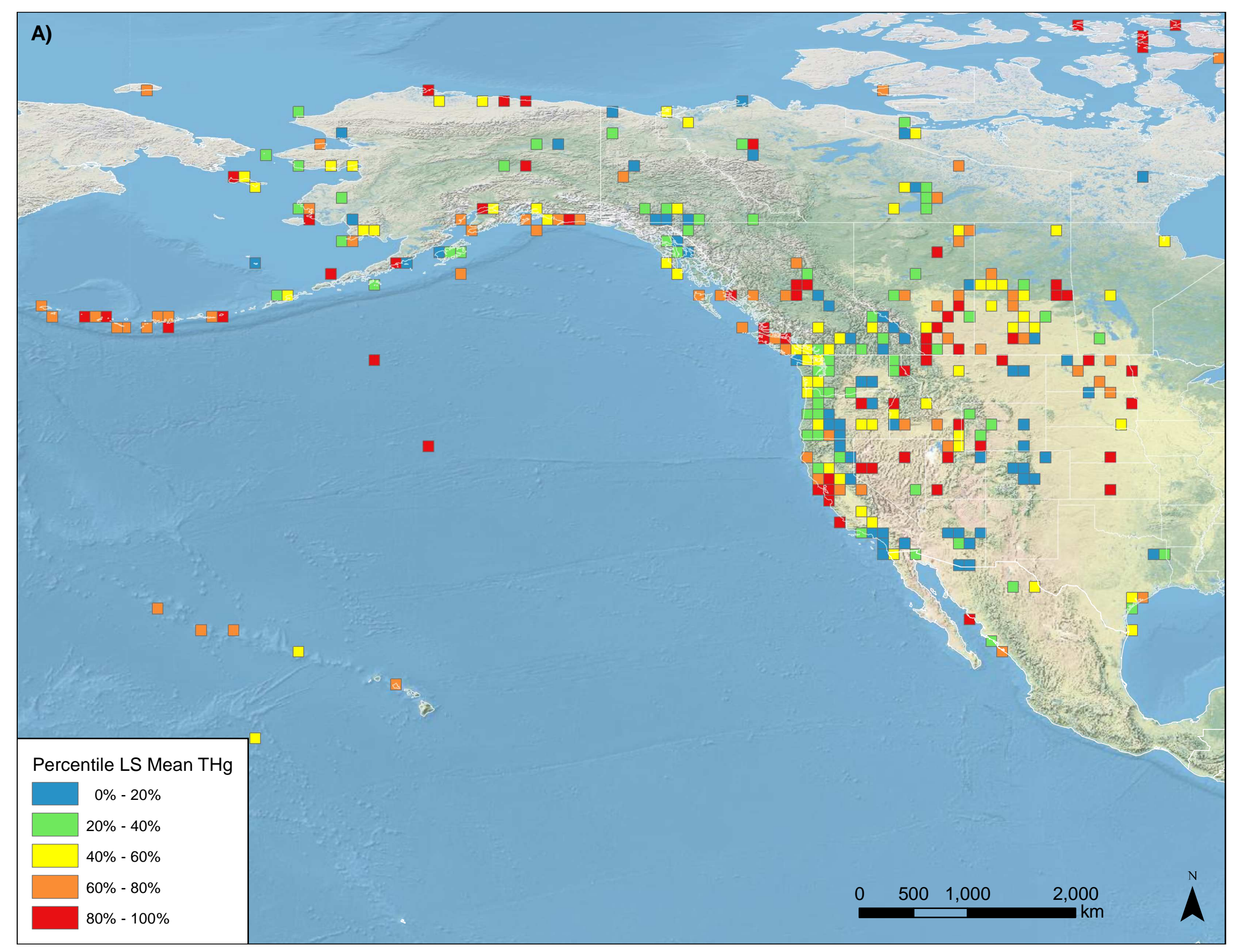


Figure 7. Blood-equivalent total mercury $(\mathrm{THg})$ concentrations in birds across western North America based on data derived from a literature review $(n=1,712$ means, representing $n=19,998$ individual samples). Each grid cell is $100 \mathrm{~km} \times 100 \mathrm{~km}$. (A) The large map on the opposite page displays grid cells by their percentile of least squares (LS) mean $\mathrm{THg}$ concentration relative to the entire dataset, such that $20 \%$ of all grid cells are represented by each color. LS mean $\mathrm{THg}$ concentrations were estimated from a model with grid cell as a fixed effect, and species and year as random effects. (B) Displays the effective sample size in each grid cell. (C) Displays the coefficient of variation (as a percentage) for the model-estimated LS mean THg concentration in each grid cell. The three maps can be used in combination to evaluate the confidence in the estimated blood-equivalent $\mathrm{THg}$ concentration in individual grid cells. The darker graduations indicate (B) smaller sample sizes and (C) greater coefficients of variation which denote lower confidence in the model-estimated LS mean THg concentrations in those grid cells.

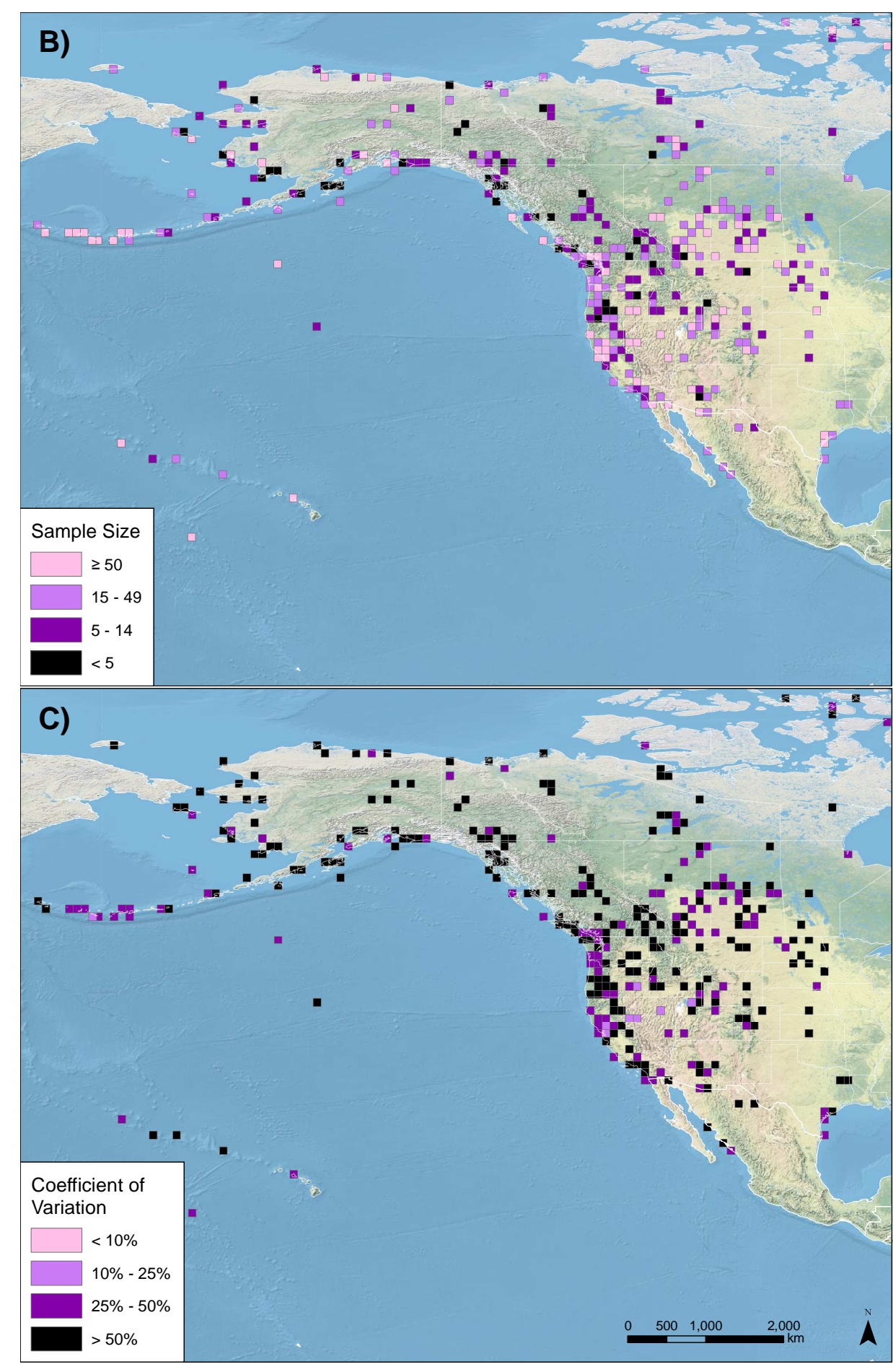


Figure 8. Blood-equivalent total mercury ( $\mathrm{THg}$ ) concentrations in birds across western North America using raw data (grid cells not hatched: $n=27,629$ individual samples) and mean data derived from a literature review (hatched grid cells: $n=1,712$ means, representing $n=19,998$ individual samples). Each grid cell is $100 \mathrm{~km} \times 100 \mathrm{~km}$. The map displays grid cells by their percentile of least squares (LS) mean THg concentration relative to the entire dataset, such that $20 \%$ of grid cells are represented by each color for each dataset. However, when grid cells had an estimated THg concentration using both the raw and literature-review datasets, priority was given to the raw data and the literature-derived estimate for that grid cell was excluded. LS mean THg concentrations were estimated separately for each dataset from models with grid cell as a fixed effect, and species and year as random effects. Red grid cells that are outlined in black indicate hotspots that were well sampled ( $>15$ samples) and had relatively low coefficients of variation $(<25 \%)$. 


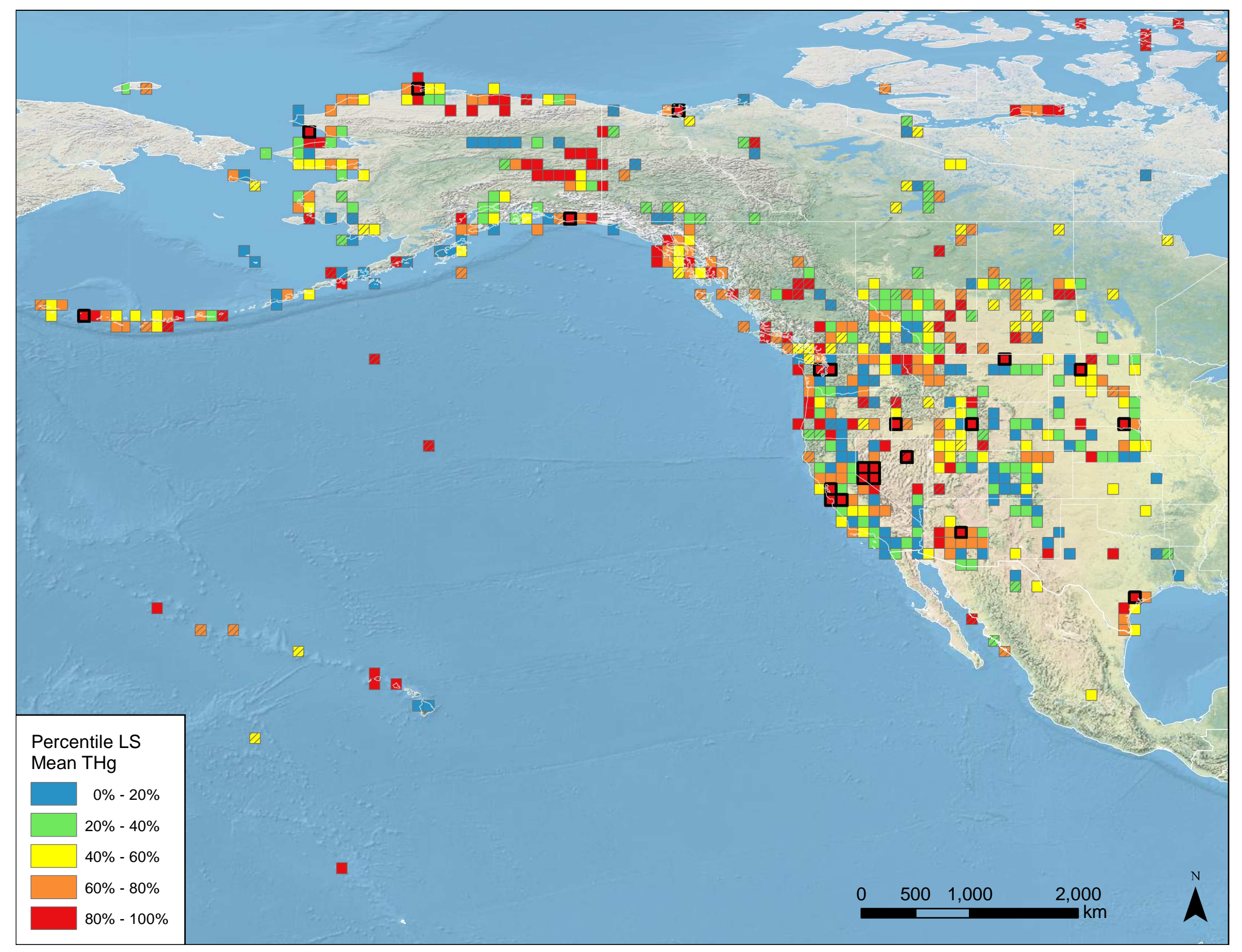


Figure 9. Percentage of individual birds sampled in western North America that are at risk to methylmercury contamination based on blood-equivalent total mercury concentrations using raw data. Only species with $\geq 60$ samples are included; see Table $S 9$ for all species. Risk categories are: $<0.2 \mu \mathrm{g} / \mathrm{g}$ ww (blue; below any known effect levels), 0.2 to $<1.0 \mu \mathrm{g} / \mathrm{g} \mathrm{ww}$ (yellow; low risk), 1.0 to $<3.0 \mu \mathrm{g} / \mathrm{g} \mathrm{ww}$ (orange; moderate risk), 3.0 to $<4.0 \mu \mathrm{g} / \mathrm{g} \mathrm{ww}$ (red; high risk), and $\geq 4.0$ $\mu \mathrm{g} / \mathrm{g}$ ww (dark red; severe risk). Brackets on the right indicate groups of species where some individuals have blood-equivalent total mercury concentrations over the specified toxicity benchmark. 


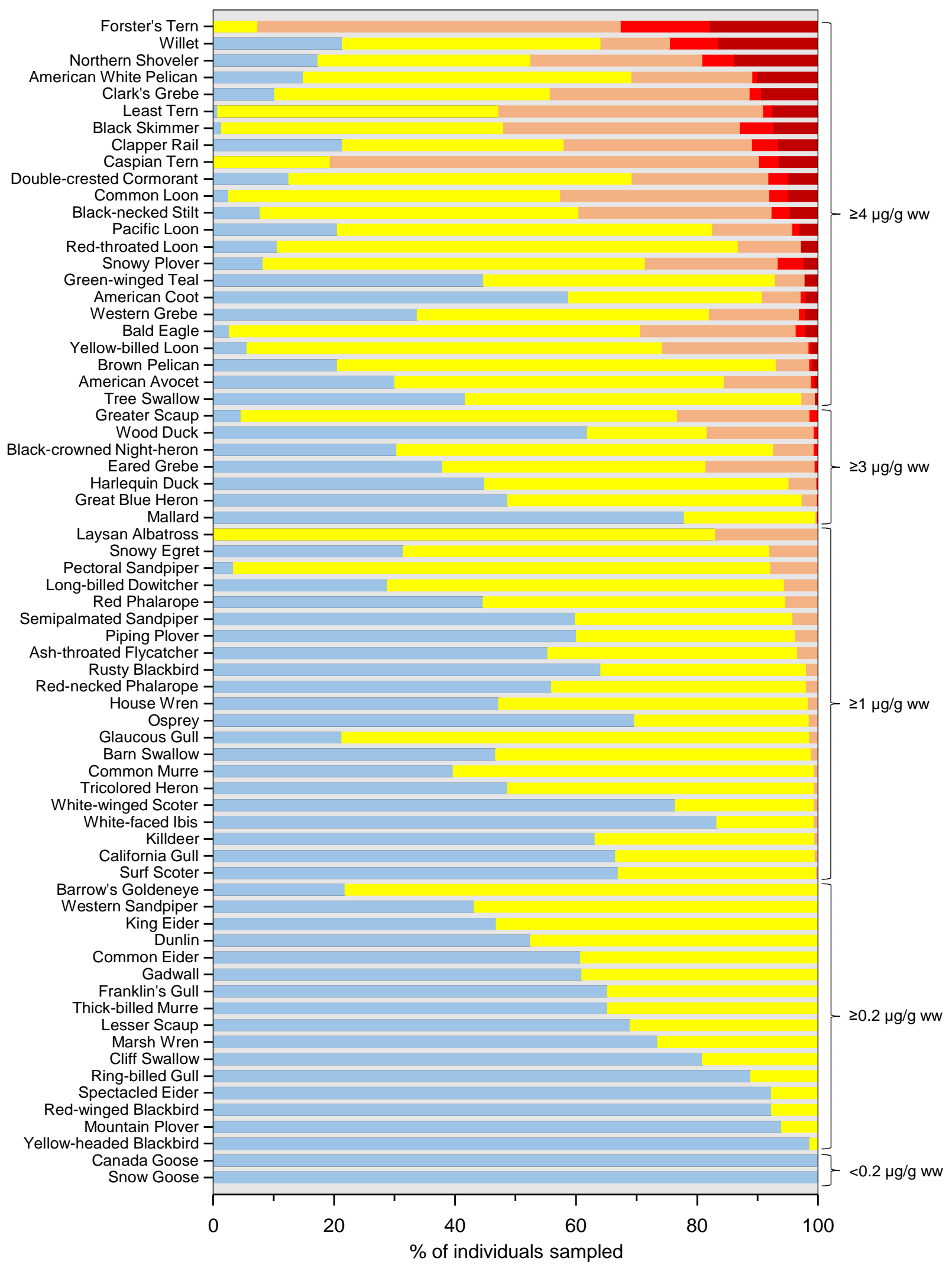




\section{Graphical Abstract}

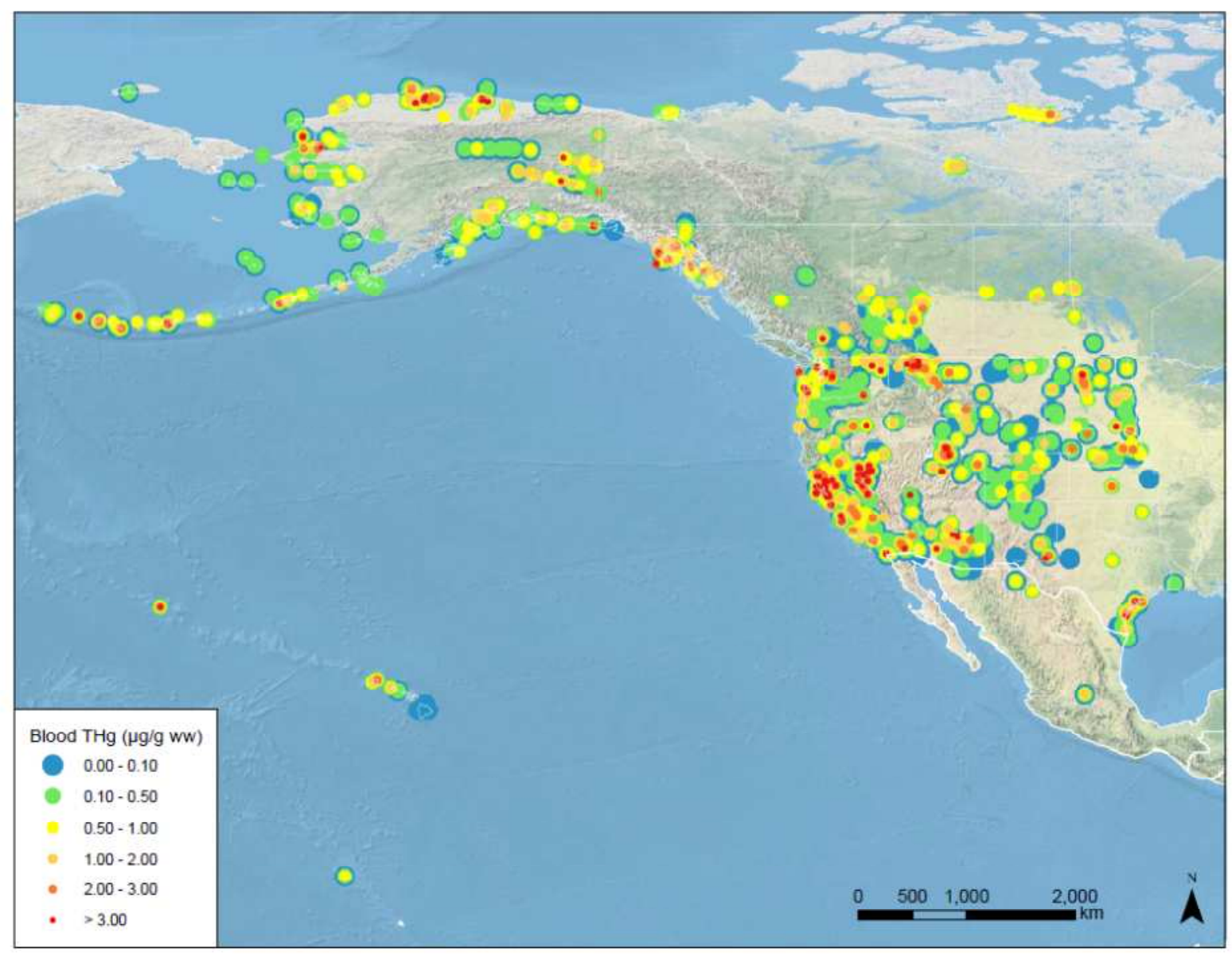




\section{Avian mercury exposure and toxicological risk across western North America: a synthesis}

Ackerman et al.

\section{Highlights:}

- Available data on $\mathrm{Hg}$ contamination of birds in western North America was compiled

- Hg differed among foraging guilds, habitats, species, locations, and ecoregions

- Hg was greatest in piscivores and carnivores, and in ocean and salt marsh habitats

- Published toxicity benchmarks were translated into blood-equivalent concentrations

- Bird Hg was above toxicity benchmarks in many areas of western North America 